\title{
Firm Size, Sovereign Governance, and Value Creation: Evidence from the acquirer size effect
}

\author{
Mark Humphery-Jenner ${ }^{\dagger}$ and Ronan Powell ${ }^{\ddagger}$ \\ Journal of Corporate Finance, Forthcoming
}

\begin{abstract}
This paper examines the relationship between acquirer size, sovereign governance, and value-creation in acquisitions. Prior literature indicates that larger acquirers' acquisitions create less shareholder wealth in developed markets, arising primarily from agency and entrenchment problems. However, in weak governance environments, size might have off-setting benefits, including increased market power and political connections. We use a sample of 17,647 takeovers from 45 countries to examine the acquirer size effect around the world. We find that the acquirer size effect exists internationally, but is smaller in magnitude in weak governance markets. Compared with larger acquirers in strong governance countries, large acquirers in weak governance countries do takeovers that generate higher stock-returns and increase post-takeover operating performance. Their deals are also more likely to be friendly, and take less time to complete. We also find that the benefits of larger acquirer size increase with the importance of political connections in the acquirer's country. The results suggest that country-governance can moderate the impact of corporate characteristics, such as corporate size.
\end{abstract}

JEL Codes: G34, G38, K22, K23

Keywords: Governance, Regulation, Takeovers, Size-Effect

\footnotetext{
* This paper benefited from comments received at seminars at UNSW and University of Technology Sydney, and at the Financial Management Association Annual Meeting (2012) and Financial Markets and Corporate Governance Conference (2013). We also thank Jeff Netter, an anonymous reviewer, Dirk Baur, Doug Foster, Jack He, Praveen Kumar, Shawn Mobbs, Marco Navone, Pascal Nguyen, Talis Putnins, Michael Skully, Eliza Wu, and Ke Yang. Humphery-Jenner thanks the Australian Research Council (ARC project number DP140103039) for financial support.

${ }^{\dagger}$ Australian School of Business, UNSW, Sydney NSW 2052, Australia. Email address: mlhj@unsw.edu.au. Phone: +61 293851000 .

* DCU Business School, Dublin City University, Glasnevin, Dublin 9, Ireland. Email address: ronan.powell@dcu.ie. Phone: +35317005000.
} 


\section{Introduction}

This paper examines the relationship between country-governance and the size-effect in acquisitions. Prior literature shows that larger acquirers tend to earn lower acquisition-returns in strong-governance countries (Moeller et al., 2004). The argued reason for this finding is that large size can insulate managers from the market for corporate control, leading to managerial entrenchment and value-destruction. However, larger firms could experience several advantages in weaker governance markets. One view is that political connections and market power can be valuable sources of shareholder wealth in weak governance markets. This is largely due to weak governance countries having weak institutions and property rights, with key players, including politicians, wielding significant power without much accountability (Fisman, 2001; Johnson and Mitton, 2003). Such political connections are more likely to exist in large, powerful companies (Farina, 2002), who are better able to exploit these advantages to increase shareholder wealth. Another view, but one with similar valuation outcomes for shareholders, is that in weak governance countries, larger size serves to protect firms from possible expropriation and government corruption. Under this view, firms have incentives to increase in size over time as a means of adapting to their environment (Lucas, 1978; Granovetter, 1995; Khanna and Yafeh, 2007; Guiso and Rustichini, 2011).

In well-governed and regulated markets, companies are better protected from sovereign rentseeking and expropriation, so larger size is likely to be less valuable in protecting shareholder wealth. Indeed, the economics and finance literature has generally focused on large size as a source of value destruction and agency conflicts in well-governed open economies (Baumol, 1962; Jensen, 1986). For example, in analyzing takeover returns, Moeller, Schlingemann and Stulz (2004) report average losses of $\$ 25$ million for large acquiring firms in the USA over the period 1980-2001. Further, Moeller, Schlingemann and Stulz (2005) show that a relatively small number of large firms account for takeover losses of over $\$ 240$ billion during the period $1998-2001$. The scale of the shareholder value-destruction through takeovers by large firms is interesting given that the USA is one of the most highly rated countries 
on a range of governance metrics, including the International Country Risk Guide (ICRG) and the World Bank (WB). One of the explanations given for such an effect is that in a strong governance country, such as the USA, firm size serves to entrench managers from external discipline from the market for corporate control (c.f. Offenberg, 2009). Noteworthy, however, is that while the losses experienced by large acquiring firms in the USA are well documented, there is a dearth of evidence on the comparative valueimplications of corporate size in an international context.

This paper examines whether and why the acquirer size effect in acquisitions varies with the governance of the acquirer's country. Our main empirical investigation begins with an examination of the relation between acquisition returns and the interaction of firm size with sovereign governance indices across our sample of 45 countries. We show that large acquiring firms tend to earn lower acquisition returns than do smaller acquiring firms, consistent with the presence of agency conflicts and managerial entrenchment. However, compared with large acquirers in strong governance countries, large acquirers in weak governance countries perform significantly better, even after controlling for a range of firm, industry, country, and time-specific factors. We hypothesize that this is because while large firms in weak governance countries may still suffer from agency conflicts related to managerial entrenchment, the benefits of large size in those countries may at least partially off-set agency-related costs.

We next explore several of the value-drivers in large-firms' acquisitions. We provide some evidence suggesting there are fewer barriers to completing takeovers by larger acquirers in weak governance countries: their deals take significantly less time to complete (controlling for other factors), than those of large acquirers in strong governance countries. Furthermore, whereas larger acquirers (compared to smaller) in stronger governance countries are more likely to be involved in costly hostile takeovers, we find that for weaker governance countries, larger size actually increases the likelihood of doing a friendly deal, which we know from our analysis, is significantly more value-enhancing. Our analysis of takeover premiums provides no evidence that the benefits of large size merely reflect expropriation from the target firm's shareholders (as opposed to actual value-creation). Further, large 
firms in weak governance markets do takeovers that are more likely to increase operating performance than are their counterparts in strong governance markets.

We also provide some additional evidence to support the view that political connections are an important value driver for larger firms in weak governance countries. We use political connections data from Faccio (2006) to examine the importance of corporate size in countries where corporate-political connections appear to be especially prevalent. We find that the benefits of large size increase significantly with the importance of political connections in a given country, implying that larger firms' deals might benefit from their connections, or at least their ability to navigate environments where connections and political issues are especially important. We also confirm this by examining sub-samples of deals (i.e. domestic deals and diversifying deals) where political connections are most likely to be important.

The results contribute to the takeover and the corporate organization literature by shedding new light on the size-effect in acquisitions. We find evidence of a size-effect in acquirer returns that extends internationally, supporting the argument that agency and managerial entrenchment costs increase with firm size. However, large acquirers in weak governance countries perform significantly better (or at least less poorly) than do large acquirers in strong governance countries. This suggests that large firms in weak governance countries enjoy some advantages, which at least partially off-set the agency-cost implications of corporate size. We provide some evidence that political connections can help to off-set the agencyrelated factors that are associated with large size. We also conduct a number of robustness tests, including using different definitions of firm size and measures of abnormal returns, and confirm that our results are robust to model specification issues. We also control for some other potential sources of heterogeneity that may explain our results, including controls for firm-level governance, and the quality of target country governance on takeover returns. We find that our results continue to hold in these robustness tests.

The outline of this paper is as follows. Section 2 discusses the prior literature and develops the hypotheses. Section 3 presents the data and defines the variables. Section 4 contains the empirical 
analysis of the impact acquirer size on acquisition performance. This section also discusses several robustness tests. Section 5 concludes.

\section{$2 \quad$ Hypothesis development}

Takeovers are an event in which an acquirer might benefit from being a larger firm in a weak governance environment. Corporations in weak governance environments can generate value by extracting rents from the government (Fisman, 2001; Chen, 2013), and by exploiting their market power to extract rents from other market participants. Larger and 'more powerful' companies are usually more politically connected (Faccio et al., 2006) and have greater market power, allowing them to extract higher rents. Strong governance is one way to reduce rents from the government (Faccio, 2006) or from market power (Khanna and Palepu, 2000). For several reasons, this would suggest that larger firms in weak governance environments enjoy several benefits that would at least partially off-set the agency-cost implications of corporate size.

First, political connections can help facilitate merger approval in developing and transitioning economies (Zhiang et al., 2009; Zheng and Singh, 2010). Faccio (2010) finds that larger firms generally have more political connections. Thus, to the extent that large firms are more connected, large firms in weakgovernance environments could use political connections to facilitate the takeover process and obtain government approval. Similarly, social ties can help to facilitate deals in weak-governance countries (Ellis, 2011), and such social networks become increasingly important as governance worsens (Roy and Oliver, 2009). To the extent that larger firms are generally seen as more 'prestigious' and tend to attract managers who are more connected (see e.g. Masulis and Mobbs, 2012), large firms should be most able to leverage social ties.

Second, political connections (which concentrate in large firms) can yield acquirer-benefiting takeovers because: (a) prestige, status and political power tend to induce a more positive target response (D'Aveni and Kesner, 1993), and this should be more important in weak-governance environments; and 
(b) there is some evidence of forced takeovers in weak governance environments and these tend to benefit larger more connected firms (MacIntyre, 2003; Volkov, 2004).

Third, given that business groups generate corporate value in weak-governance environments (He et al., 2013), large firms could use their dominant position as a form of non-pecuniary acquisition currency with which to entice target-firm shareholders (Khanna, 2000).

Fourth, given that (a) lenders in weak governance requirements often require high levels of assetbacked collateral (Menkhoff et al., 2006), and (b) large firms are more able to satisfy this requirement, large firms might be best able to finance takeovers. This advantage should concentrate in weak governance environments where collateral is more important.

Fifth, large size is a protective mechanism that is 'adapted' to weak governance environments and is relatively less useful in good governance environments. For weak governance environments, organizations may increase in size as a way to protect themselves from government intervention and political instability (Granovetter, 1995; Khanna and Yafeh, 2007). This is particularly important where the governance environment, weak contract law, and the lack of the rule of law may make external transactions risky (consistent with Chang and Hong, 2000; Khanna and Palepu, 2000; Khanna and Yafeh, 2007). Subsequently, there is some related evidence that resource-rich parties tend to perform better in litigation in emerging markets ( $\mathrm{He}$ and $\mathrm{Su}, 2013)$. However, this 'protection' aspect of large size is mainly adapted to weak governance environments. Thus, it becomes less useful in strong governance environments, where large size may offer 'excess' protection from external market forces, and may enable managers to act on agency conflicts (Moeller et al., 2004, 2005; Humphery-Jenner and Powell, 2011). Subsequently, the 'excess' protection from market forces in strong governance countries might destroy shareholder wealth. This suggests that while large size increases shareholder wealth by protecting firms in weak governance countries, in good governance countries it might destroy shareholder wealth by offering excess managerial protection and reducing managerial discipline. This background enables us to make the following 'value-creation' hypothesis. 
Hypothesis 1: Value-creation hypothesis. The market will react more positively (or at least less negatively) to deals made by large companies in weak governance countries as compared with those made in strong governance countries.

We next consider several possible reasons for why the market might respond more favorably to large acquirers' acquisitions. First, larger firms might be able to use their connections and resources to reduce the time required to complete a deal. Reducing completion times can be value-creating given that (a) acquisitions are often costly due to the presence of financial intermediaries (see e.g. Krishnan et al., 2012; Krishnan and Masulis, 2013), and (b) the longer a deal remains open the more scope there is for a competing bidder to place a bid, thereby increasing acquisition premiums and creating the risk of a winner's curse (Giliberto and Varaiya, 1989; Boone and Mulherin, 2008). The 'completion time' hypothesis captures this prediction.

Hypothesis 2: Completion-time hypothesis. In weak governance countries, larger firms take less time to complete a deal, compared to large in stronger governance countries.

Second, larger acquirers in weak governance countries might be more able to undertake a 'friendly' deal than larger in strong governance countries. This might arise for several reasons, including political connections, increased market power, and greater financial resources. These factors might encourage a potential target to acquiesce to a deal rather than to compete with the bidder. Further, a larger firm might be more able to finance an adequate takeover premium, which would reduce the likelihood of dealresistance. Subsequently, we make the following 'deal mood' hypothesis.

Hypothesis 3: Deal-mood hypothesis. In weak governance countries, larger firms will be more likely to undertake a 'friendly' deal compared to larger firm in strong governance countries. 
Third, it might be possible that larger firms' acquisitions in weak governance countries (compared with those in strong governance countries) perform better because they are able to use their market-position to pay lower premiums and 'expropriate' wealth from the target's shareholders. The simple fact of paying lower takeover premiums could result in the market responding more positively to large firms' acquisitions in poor governance countries. We capture this with the 'takeover premium' hypothesis.

Hypothesis 4: Takeover premium hypothesis. Large firms in weak governance countries pay lower takeover premiums than do large firms in strong governance countries.

We further anticipate that in weak governance countries, large firms will have some advantages over their counter parts in strong governance countries due to the utility of political connections. While political connections (and expenditures) are important in developed markets (Coates, 2012), they are significantly more important in comparatively weak governance markets (Chen et al., 2010; Brockman et al., 2013). Subsequently, in weak governance markets, we hypothesize that firm size is important in those types of deals where government intervention is more likely to be important. First, government connections are likely to be more important when the firm is undertaking a domestic takeover for another firm in the bidder's country than it is for a cross-border deal. Second, government-intervention is likely to have the most adverse consequences for diversifying deals, as the government directs diversifying acquisitions which do not create shareholder wealth (Fan et al., 2008). Given that we expect that large firms in weak governance markets will be more able to resist such government intervention, we expect that they will perform comparatively better in these diversifying deals. We also examine the role of acquirer size in countries where political connections are more dominant in corporate boards, on average.

Hypothesis 5: Connections hypothesis. In weak governance countries, larger size is helpful in those types of deals that are more likely to rely on connections (although, this does not mean that large size 
is not important in other types of deals). The benefits of larger size should increase with the importance of political connections in the acquirer's country.

Improvements in operating performance (as opposed to simply obtaining a cheap target) can be a key source of value-creation. We expect that larger firms in weak governance countries will do takeovers that are more likely to increase long-run operating performance. A value-creating takeover should both be associated with a more positive market reaction and should increase operating performance (Li, Forthcoming; Healy et al., 1992; Powell and Stark, 2005; Harford et al., 2012). We expect that large firms in weak governance countries will be more likely to experience operating improvements than their counterparts in strong governance countries. This is because (from the foregoing discussion) while large firms in both weak governance and strong governance countries might suffer agency conflicts of managerial-entrenchment, large size conveys some additional wealth-enhancing benefits in weak governance countries. These benefits will at least partially off-set some of the agency costs related to large size. Examining operating performance also has the empirical benefit of helping to validate the short-run market-returns results with longer-run results. Subsequently, we make the following hypothesis.

Hypothesis 6: Operating performance hypothesis. Large firms in weak governance countries are more likely to do takeovers that increase operating performance than are large firms in strong governance countries.

\section{Data}

The full sample comprises of 17,647 takeover observations from 45 countries. The takeover data is extracted from Thomson's SDC platinum and we analyze takeovers announced between 1996 and 2008. The results are robust to excluding the financial crisis year 2008, and years associated with the Asian Financial Crisis. We obtain stock-return data from Datastream. Acquirer level financial data is extracted 
from Worldscope. Governance data is taken from the World Bank's governance indicators site and from the International Country Risk Guide (ICRG). We restrict the sample to takeovers that are for at least USD $1 \mathrm{~m}$, are completed, and for which the acquirer owns less than $50 \%$ of the target before the takeover and holds $100 \%$ of the target after (consistent with Masulis et al., 2007; Harford et al., 2012). Table A1 in Appendix 1 contains a detailed description of the variables and their calculation.

\subsection{Dependent variables}

We use the acquirer's cumulative abnormal return (CAR) around the acquisition announcement as a proxy for whether the deal creates value. We use an 11-day market-adjusted CAR. We choose an 11-day window because some markets have weak stock exchange rules, giving rise to potential leakage and pretakeover informed trade, which a longer window will capture. Using alternative windows (e.g., 3-day, 5day, 21-day) does not alter our findings (untabulated). The market return is the return earned on the market index for the firm's market as indicated in DataStream. We used a market-adjusted model over a market model because many of the deals in our sample occur in countries with fairly illiquid markets. This illiquidity could bias the estimation of market model parameters (Dimson, 1979; Dimson and Marsh, 1983). Nevertheless, in untabulated results, our findings are robust to using market model based CARs, where the model parameters (alpha and beta) are estimated using OLS regressions over 200 days $(-210,-11)$ prior to the takeover announcement for each firm. We also use methods (untabulated) advocated by Dimson (1979) and Scholes and Williams (1977) to adjust the market model parameters for nonsynchronous trading, and find results consistent with our market-adjusted models. For brevity and reporting convenience, we only tabulate results using the market-adjusted model.

We collect data from SDC on the time-to-completion and the deal mood in order to address Hypothesis 2 and Hypothesis 3. We measure the time to completion (the dependent variable) as the time between the announcement of the deal and the completion of the deal. We capture the deal mood by creating an indicator that equals one if the deal is 'friendly' (i.e. is not hostile, as reported in SDC). 
We measure the takeover's long run operating performance by obtaining data on the acquirer's EBIT/Assets in the years after the acquisition (in order to address Hypothesis 6). We create indicators for whether the acquirer's EBIT/Assets 1, 2, or 3 years after the takeover exceeds its EBIT/Assets 1-year before the takeover announcement (for three variables in total).

\subsection{Size and control variables}

The key independent variable is the acquirer firm size variable, defined as the natural log of the firm's book assets, denoted 'In(Assets)'. Using the natural log of the firm's market capitalization does not alter our findings. We also include a number of control variables that are standard to the literature (see, e.g., Harford, Humphery-Jenner and Powell, 2012; Humphery-Jenner and Powell, 2011; Moeller et al., 2004; Moeller and Schlingemann, 2005; Moeller et al., 2005; Masulis et al., 2007; and Travlos, 1987). Specifically, we include relative size of the target, Tobin's q, return on assets, capital expenditures, free cash flow, leverage, and indicator variables for diversifying deals, all cash, all stock, target organizational status (i.e., public, private or subsidiary), competed deals, and friendly deals. We also control for country-level characteristics to ensure that sovereign governance does not merely proxy for country-level growth characteristics. We include the market capitalization of the home market scaled by GDP (at the end of the prior year), the stock turnover ratio in the home market over the course of the prior year, and the amount of FDI, unemployment, and the trade imbalance in the prior year. The country-level variables are sourced from the World Bank.

\subsection{Governance variables}

We use governance variables that capture government-based expropriation and corruption. Note that we do not focus on shareholder protection. This is because we analyze the use of corporate size as a mechanism of protection from the government. Measures of shareholder protection would not capture this type of government corruption. 
We use World Bank governance variables, which capture different types of government corruption and risk, and have also received extensive use in the literature (Neumayer, 2002; Dollar and Kraay, 2003; Apodaca, 2004; Braun and Di Tella, 2004; Thomas, 2010). We focus on these measures of country governance because they reflect varying types of corruption, government effectiveness, and the rule of law. We do not focus on the ADRI indices (cf La Porta et al., 1997; Spamann, 2010) because they only capture shareholder protection, and do not capture government expropriation, which is the focus of this study. They are also time invariant, so will not capture changes due to financial liberalization. By contrast, the World Bank variables are available in most years. ${ }^{1}$

The first governance variable is the World Bank governance variable. The World Bank variable is based on six World Bank sub-variables. The six World Bank variables are percentile ranks in terms of accountability, government effectiveness, political stability, regulation, the rule of law, and corruption. We compute a composite governance index (WB governance index), which is the equally weighted average of these six percentile ranks. We also use the ICRG political risk index. These variables capture (weak) sovereign risk. In all cases, a higher governance score indicates stronger governance.

\subsection{Political connections measures}

We obtain the political connections measures from Faccio (2006), as indicated above. We focus on the level of political connections at the aggregate country level. We do this for two reasons. First, it allows us to use the data in Faccio (2006) for the full time-period under-analysis. If we were to use the firm-specific data in Faccio (2006), then we would be limited to the set of firms that existed at the time of the study. Second, using sovereign-level data allows us to avoid concerns about endogeneity between corporate size and political connections.

We use three proxies for the importance of political connections in the acquirer's country. First, we use the percentage of all firms that had as one of their top officers a member of parliament or head of

\footnotetext{
${ }^{1}$ The World Bank provides figures for 1996, 1998, 2000, 2002, 2003, 2004, 2005, 2006, 2007, and 2008. For the years with missing data we use the figure from the most recent prior year.
} 
state. Second, we use the percentage of all firms who satisfy the first definition, or had a top officer who was a close relative of a member of parliament or head of state. Third, we use the percentage of the top 50 firms (by market capitalization) who have a top officer who is either a member of parliament or a head or state, or is a close relative thereof. The percentages are based on the sample of all Worldscope firms.

\subsection{Univariate analysis and sample description}

The sample composition by year is reported in Table 1. The summary statistics for the variables are reported in Table 2 . All continuous variables are winsorized at the $1 \%$ level by country. We report CARs and \$CARs using both the market-adjusted model (MAM) and the market-model (MM). The positive average CARs of $1.31 \%$ (MAM) or 1.92\% (MM) reported in Table 1 are consistent with prior studies and suggest that acquiring firms, on average, gain from takeovers. The higher mean CARs for the MM confirm our illiquidity concerns with respect to some of the less well-developed economies in our sample. More specifically, in markets that suffer from illiquidity problems, stocks may not trade on a daily basis, so beta estimates from a market model will be biased downwards (Dimson, 1979; Dimson and Marsh, 1983), giving rise to lower expected returns, and higher abnormal returns. Nevertheless, both MAM and MM CARs are positive and statistically significant. However, we find differences in the sign for \$CARs, with negative average values $(\$ 1.65 \mathrm{~m})$ for MAM returns, and positive $(\$ 0.40 \mathrm{~m})$ for the MM returns. Given our concerns about illiquidity, we place more confidence on the MAM values, so on the basis of the negative \$CAR, we conclude that our results confirm the existence of a size-effect across our sample. Table 1 also shows some variation in takeover activity over time, with higher activity and clustering during the late 1990s, and again during the 2004-2007 period (Ahern and Harford, Forthcoming; as per Andrade et al., 2001; Powell and Yawson, 2005). The statistics show the existence of some large dollar losses in takeovers during the 2000 and 2001 period, which overlaps with the time period of large losses as reported by Moeller et al. (2005) for the USA market. However, as we will see later, large losses are not 
solely driven by the USA market. To control for unobserved year effects, we use year dummies in our regression models.

Table 2 reports summary statistics for the variables used in our multivariate regression models. The WB composite index and the ICRG political index (Panel A) have mean values of 0.89 and 0.84 respectively, indicating that on average, governance levels are fairly high. Some variation is evident, however, with reported standard deviations of 0.08 and 0.05 , respectively. Other acquirer and deal characteristics are fairly consistent with prior studies, except that given the nature of our sample we report a much higher proportion of cross-border deals at $26 \%$ and diversifying deals at $67 \%$.

Table 3 reports the CARs and governance-indexes by country. The CARs are based on a market adjusted approach (MAM). The table shows that there is significant variation in CARs across countries, largely varying with the quality of the governance in that country. There is significant variation in country-level governance. The components of the World Bank governance index largely move together, suggesting a high level of correlation between the different aspects of governance.

We compare the CARs accruing to large firms in good governance countries with large firms in weak governance countries in Table 4. In Table 4, we split the sample into terciles, quartiles, and quintiles in terms of the firm's assets and the World Bank governance score for the firm's country. We report the mean and median CAR and the number of observations for each group. The CARs are the 11-day marketadjusted CARs. We split the sample into acquirer-size groups and within each group look at the CARs in each governance sub-group. For example, within asset tercile 3 (i.e. the top $33 \%$ of acquirers in terms of size), we analyze CARs for each of the governance terciles. We present the difference-in-CARs between the worst governance group and the best governance group. There are two key findings. First, large acquirers tend to perform worse than do small acquirers. This is consistent across governance-groups. Thus, we find evidence of a size-effect internationally. Second, for the large acquirers (i.e. top tercile, quartile, or quintile), firms in weaker governance countries earn higher CARs than do firms in stronger governance countries. That is, the size effect is less pronounced. Overall, this indicates that while the size effect exists 
outside of the USA, large acquirers perform comparatively less poorly in weak governance countries. This suggests that large size could convey benefits in weak governance countries that at least partially off-set the agency-related disbenefits of large acquirer size.

\section{$4 \quad$ Results and analysis}

\subsection{Size, governance and CARs (Hypothesis 1)}

The goal is to examine how sovereign governance moderates the impact of firm size on takeover profitability. The expectation is that larger firms perform better in weak governance countries. We capture this expectation in the following model.

$$
\mathrm{CAR}_{j}=\alpha+\beta^{(1)} \ln (\text { Assets })_{j}+\beta^{(2)} \mathrm{GOV}_{j}+\beta^{(3)}\left(\ln (\text { Assets })_{j} \times \mathrm{GOV}_{j}\right)+\boldsymbol{\theta} \boldsymbol{X}_{j}+\lambda_{t}+\varepsilon_{j}
$$

We expect that $\beta^{(3)}$ will be negative, implying that larger acquirers in strong governance countries generally do worse deals. We also examine models where we create dummy variables for whether the acquirer is a 'large' firm, and whether it is in a 'weak' governance country. Specifically, we create three larger size dummy variables, which take the value of one in each case if the acquirer assets (US\$) are in the top $50^{\text {th }}, 25^{\text {th }}$, or $10^{\text {th }}$ percentile of all firms, and zero otherwise. To capture weak governance, we create a dummy variable equal to one if the acquirer's country-level governance index is below the median value across all countries. The model specification is as follows.

$$
\begin{aligned}
\mathrm{CAR}_{j}= & \alpha+\beta^{(1)} \text { Large Acquirer Dummy } \\
& +\beta^{(2)} \text { Weak Gov Dummy }_{j} \\
& +\beta^{(3)}(\text { Large Acquirer Dummy } \\
& \left.\times \text { Weak Gov Dummy }_{j}\right)+\boldsymbol{\theta} \boldsymbol{X}_{j}+\lambda_{t}+\varepsilon_{j}
\end{aligned}
$$

Where the variables are defined as above, with the exception that the model focuses on dummy variables.

Here, we expect that $\beta^{(3)}$ will be positive, implying that larger acquirers in weak governance countries generally do better deals. We estimate the models in Equations (1) and (2) by using OLS regressions that include year dummies and cluster standard errors by four-digit SIC industry (following Petersen, 2009).

Table 5 reports OLS regressions based on equations 1 (columns 1-4) and 2 (columns 5-8). Columns 1 and 2 show no significant relationship between CARs and firm size. This is not surprising given that 
Tables 3 shows significant variations in acquirer returns across size/governance portfolios, suggesting that sovereign-heterogeneity might influence the size/CARs relationship. Columns 3 and 4 include the interaction terms 'In(Assets) x WB Gov.' and 'In(Assets) x ICRG Political Index'. The negative and significant coefficients on the interaction terms indicate that sovereign governance negatively moderates the impact of corporate size on takeover returns. When combined with the positive coefficient on $\ln$ (Assets), this suggests that while large size can convey some benefits in weak governance markets (in the form of connections and market power) these traits are less useful in stronger governance markets. We obtain similar results in Columns 5-8, which contain dummy-variable regressions as in Equation 2. The interaction term, which now captures the returns to large acquirers in weak governance countries, is positive and statistically significant for all definitions of 'large' (i.e., top $25^{\text {th }}, 10^{\text {th }}$ percentiles), confirming that large acquirers takeovers in weak governance are, on average, value creating. Thus, in stronger governance markets, firm size can induce agency conflicts of managerial entrenchment, which mitigate any benefits the firm might otherwise gain from its size.

The other control variables representing acquirer and deal characteristics generally have signs consistent with the literature. Relative size is positive and significant indicating that scale increases returns to the average deal, which is, on average, value-enhancing for acquirer shareholders, as reported in Table 2. Acquirers with higher leverage earn lower returns, consistent with higher financial risk. Tender offers, which may capture deal hostility, generate higher returns consistent with the disciplinary motive for takeovers (Jensen and Ruback, 1983; Jensen, 1986; Scharfstein, 1988). Stock swap deals generate lower returns, which is consistent with overvaluation and information asymmetry motives as reported in prior studies (Travlos, 1987). Targeting both public and private targets appears to reduce returns relative to subsidiary targets, however, the larger negative coefficient on public is consistent with larger losses in targeting publicly listed targets (Chang, 1998; Fuller et al., 2002). Substituting the public dummy variable for a subsidiary dummy (untabulated) confirms that both private and subsidiary deals earn significantly greater returns than public. The coefficient on the private dummy variable is marginally 
smaller, confirming that subsidiary deals earn the highest returns. The positive coefficient on ROA is consistent with the idea that higher quality managers tend to induce higher ROA, and higher quality managers may select more appropriate targets (Shleifer and Vishny, 1989).

The results provide some initial support for our first hypothesis, that larger acquirer takeovers in weak governance countries create greater value for acquirer shareholders.

\subsection{Takeover approval and completion times (Hypothesis 2)}

The next set of models examine whether larger firms in weak governance markets complete deals more quickly. We use a similar regression specification to (1) and (2) above. Hypothesis 2 examines whether larger firms in weak governance markets complete deals more quickly. We measure the time to completion (the dependent variable) as the time between the announcement of the deal and the completion of the deal. Table 6 reports OLS regressions that examine the impact of acquirer size and country governance on deal completion times. The results are also robust if we use a tobit specification instead of OLS (untabulated). Columns 1 and 2 use continuous size and governance variables. Columns 3-6 use size and governance dummy variables. The results in Columns 1 and 2 indicate that in stronger governance countries, larger companies take longer to complete deals than their smaller counterparts, suggesting that large companies face greater regulatory barriers in stronger governance countries. Conversely, the coefficients on the interaction terms (i.e. 'Weak WB Gov. x Size Top 10\%' and 'Weak Political Gov. x Size Top 10\%') in Columns 3-6 highlight that in weak governance markets, larger companies take significantly less time to complete deals. ${ }^{2}$ The statistically stronger results for the largest firms in our sample are consistent with our hypothesis that political connections will be concentrated in the largest firms.

\footnotetext{
${ }^{2}$ While the coefficients on the governance variables are negative and large in magnitude, this does not imply that the deal takes a 'negative' period to complete; instead, the similarly large constant term and the presence of interaction variables, suggests that deals have a positive time-to-completion.
} 


\subsection{Deal mood (Hypothesis 3)}

Another mechanism whereby political connections can manifest in the takeover process is in the mood of the takeover. Hypothesis 3 predicts that stronger political connections may facilitate more friendly deals, which are likely to be less expensive for the acquirer. For these regression models, the dependent variable is a dummy indicator that equals one if the deal is 'friendly' in nature (i.e., target management recommend bid acceptance) and equals zero otherwise. The models are estimated using logit regressions.

Table 7 examines this further by testing whether larger firms in weak governance countries are significantly more likely to undertake friendly deals. The results are consistent with expectations. The interaction term in Columns 1 and 2 indicates that large firms in stronger governance countries are less likely to do friendly deals. Conversely, the interaction term in Columns 3-6 indicates that larger acquirers in weak governance countries are significantly more likely to do friendly deals than are larger acquirers in strong governance countries (or smaller acquirers in weak governance countries). We interpret this as evidence that political connections help facilitate friendly deals, which in part explain the larger returns earned by large acquirers in weak governance countries.

\section{4 'Expropriation' from the target's shareholders (Hypothesis 4)}

Hypothesis 4 predicts that one avenue in which acquirers can create value for their own shareholders is by 'expropriating' wealth from the target's shareholders by paying a low acquisition premium. We test this by calculating the takeover premiums that firms pay in acquisitions of listed targets (we cannot obtain data for unlisted targets because there is no pre-acquisition market value for these targets). The dependent variable is measured as the transaction value scaled by the target's market value one week or four weeks before the takeover. This is a relatively standard way to compute takeover premiums (Humphery-Jenner and Powell, 2011; Harford et al., 2012; Alexandridis et al., 2013).

We report models that examine takeover premiums in Table 8. The negative and significant coefficient on the interaction terms suggests that larger acquiring firms in strong governance countries 
pay lower premiums, on average, than do smaller firms. The negative, but insignificant firm size coefficients indicate that premiums, on average, do not differ significantly between large and small acquirers in weak governance countries. This is opposite to our prediction for hypothesis 4, and suggests that the size/governance effect does not merely reflect large acquirers in weak governance countries expropriating value from target firm shareholders. The inferences are unchanged when we use the size dummy variable specification as denoted by equation 2 (untabulated).

\section{Government connections (Hypothesis 5)}

This section examines in more detail the linkages between larger acquirers in weak governance countries and political connections.

First, we examine whether large acquirers in weak governance countries perform better than large acquirers in strong governance countries in the types of deals for which connections might be more important. Specifically, we explore whether the large firms' benefits accrue in domestic deals and diversifying deals (Table 9). We anticipate that larger firms' advantages will especially manifest in domestic deals because these deals are more likely to benefit from large firms' hypothesized political connections. Further, given that (a) government-mandated deals and government intervention can induce value-destroying diversification (Fan et al., 2008), and (b) we expect large firms to be more able to resist such government-directed deals, we anticipate that large firms in weak governance markets will do better in diversifying deals than will small firms. The models in Table 9 estimate the CARs regressions (Equations 1 and 2) for sub-samples of domestic deals and diversifying deals. The results are largely consistent with expectations. Panel A uses continuous size and governance variables and Panels B-C use size and governance dummy variables. The results indicate that large firms perform better (worse) in weak (strong) governance markets in domestic deals and in diversifying deals. This implies that large firms are more able to use their connections to both pursue domestic deals and resist value-destroying diversification. 
The second set of models uses the country-level measures of the importance of connections. We expect that larger firms will perform better in countries where political connections are more important. We use the data on aggregate country-level political connections from Faccio (2006) to examine the importance of corporate size in countries where political connections appear to be especially important. Faccio (2006) collects data on corporate political connections in 47 countries. The data pertains to the period of 1997 to 2001. Faccio (2006) provides aggregate country-level data on the percentage of firms who have a member of parliament, head of state, or close relative thereof as a top officer. We use these country-level variables to analyze the importance of size in countries where connections appear to be especially prominent and important. We focus on country-level variables because (a) they allow us to get an overall picture of the importance of connections in the acquirer's country, (b) they allow us to retain our full time-period (as opposed to just looking at the point in time underlying the Faccio (2006) dataset, and (c) they obviate concerns over endogeneity between the firm's specific level of connections and its size. This dataset has received significant use in the literature (Faccio, 2006, 2010). We exclude from the sample firms that are listed in the United Kingdom because the UK presents a significant outlier in the Faccio (2006) dataset. Specifically, Faccio (2006) reports that 46\% of the top 50 UK firms have political connections. It is not economically sensible that nepotism-through-connections would be so widespread in a country that otherwise scores highly in all metrics of sovereign governance. We estimate the following model.

$$
\begin{aligned}
\mathrm{CAR}_{j}= & \alpha+\beta^{(1)} \ln (\text { Assets })_{j}+\beta^{(2)} \text { Sovereign Connection Rate } \\
& +\beta^{(3)}\left(\ln (\text { Assets })_{j} \times \text { Sovereign Connection Rate }_{j}\right)+\boldsymbol{\theta} \boldsymbol{X}_{j}+\lambda_{t}+\varepsilon_{j}
\end{aligned}
$$

Where, Sovereign Connection Rate ${ }_{j}$ denotes one of the three key measures of the average level of political connections in the acquirer's country. The measures are the percentage of all firms in the acquirer's country who have as one of their top officers or large shareholders either (a) a member of parliament or head of state, or is (b) closely related to a member of parliament or head of state. We also examine the 
percentage of the top 50 firms in the country who have as a top officer a member of parliament/head of state or a close relative of such.

We report these models in Table 10. As indicated above, we exclude acquirers in the United Kingdom from the sample given that they represent an outlier in the Faccio (2006) dataset. The main finding is that the coefficient on the interaction term is significant and positive, suggesting that the benefits of corporate size increase with the importance of political connections in a country.

\subsection{Operating performance (Hypothesis 6)}

We expect that large firms in weak governance markets will do takeovers that yield greater improvements in operating performance (hypothesis 6). We capture this by creating indicators for whether the acquirer's EBIT/Assets 1, 2, or 3 years after the takeover exceeds its EBIT/Assets 1-year before the takeover announcement (for three variables in total). We estimate these models using logit regressions.

The results reported in Table 11 indicate that in weak governance markets, large firms' acquisitions are more likely to increase operating performance. The coefficient on 'In(Assets)' is positive and statistically insignificant, implying that firm size does not per-se significantly increase the likelihood of operating performance improvements. The coefficients on the governance variables, 'WB Gov Index' and 'ICRG Political Index' are positive (in all but one case) and sometimes statistically significant, suggesting that takeovers, on average, tend to perform better when they are conducted by acquirers in a stronggovernance market. The negative, and statistically significant coefficient on the interaction terms implies that large firms perform comparatively worse in strong governance markets than they do in weak governance markets. 


\subsection{Additional robustness tests}

In this section we report the findings of some additional tests that further test the robustness of our findings to alternative firm size definitions, and to other sources of heterogeneity that might explain why larger firms perform better (worse) in weak (strong) governed countries. Due to the large number of additional tests conducted, we do not tabulate them for reporting convenience. They are, however available from the authors on request.

Measuring firm size: We measure firm size as a continuous variable, and by using size dummy variables. Both measures do not take into account relative size differences across countries. Nevertheless, we repeat our analysis using size measures that capture the relative size within each country. Specifically, for each country, we define large dummy variables by allocating acquiring firms to the top $25^{\text {th }}$ and $10^{\text {th }}$ percentiles in assets of local currency. Our results remain unchanged.

Firm-level governance: Firm-level governance quality could be argued as a potential source of heterogeneity between firms that may not be captured by our country-level governance variables. Given the scant availability of corporate governance measures (e.g., board and ownership data, shareholder rights indices) for most of the countries in our sample, we develop a proxy measured as the absolute level of discretionary accruals. The level of discretionary accruals is argued to reflect the quality of earnings and the earnings management (Jones, 1991; Dechow et al., 1995; Dechow and Dichev, 2002). The idea here is that earnings management is more likely to occur in weakly governed firms, possibly due to weak oversight by the board, and/or weak internal control and audit systems (Beasley, 1996; Becker et al., 1998; Chtourou et al., 2001). We measure discretionary accruals using the modified Jones (1991) approach. We do not use accruals-variables in the reported models because even requiring data on discretionary accruals significantly reduces the sample size (to 11,349 observations). Including the absolute value of discretionary accruals to total accruals in our models does not alter our conclusions. 
Target country governance: We also examine whether the sovereign governance in the target's country influences acquirer takeover returns. Target-country governance is incrementally relevant only if the deal is cross-border (for a domestic takeover, the target and acquirer have the same governance). Thus, we constrain our sample to include only these takeovers. The results indicate that target country governance has no significant impact on acquirer profitability.

Country-effects: The results are not riven by observations deriving from any one country. The results are robust to omitting observations from the USA (which account for a large portion of the sample). We also find similar results to Moeller et al (2004) if we restrict the sample to contain only companies from the USA. Further, we also employ a weighted least squares (WLS) specification that down-weights acquisitions made by acquirers in countries that feature many observations (specifically, weighting each observation by the inverse of the proportion of deals (in dollar terms) that come from the acquirer's country). The WLS approach is probably preferable to simply omitting observations from particular countries. For example, if we omit the USA, then the UK, Australia and Canada comprise two-thirds of the remaining sample. The results for the WLS models are consistent with the reported regression results. The results are also qualitatively robust to including acquirer and/or target country-fixed effects.

Alternative governance and omitted variables: The results are robust to using different measures of sovereign governance. We focus on the variables that are most associated with political risk and that have the potential to vary over time as countries develop. Nonetheless, the results are qualitatively similar if we use measures such as the anti-director rights index (as per La Porta et al., 1997), or the anti-self-dealing index (as per Djankov et al., 2008). Further, the results are robust to whether we use the original index or the updated version from Spamann (2010). The robustness across governance variables likely reflects the high degree of correlation amongst measures of sovereign governance. 
We also examine whether omitted variable bias poses a problem for our models. One variable that is absent from our models is a direct measure of market power. While our models include industry dummies, which should capture some of the effects of greater market power, we nevertheless re-estimate the models including the Herfindahl-Hirschman Index (HHI), and find that our findings remain largely unchanged. The HHI term is positively related to acquirer CARs, consistent with the idea that marketpower-motivated acquisitions can improve acquirer-value.

The results are also robust to controlling for the amount of M\&A activity in the acquirer's country. We do this to control for the likelihood that the market for corporate control is less competitive in weak governance countries. We find that while the level of M\&A activity is negatively related to acquirer CARs, the results are qualitatively the same as those reported in the paper.

Government ownership and sovereign wealth fund involvement: One concern is that the results might merely reflect government owned institutions making connected deals. However, only 91 acquirers have government or sovereign wealth fund ownership, and the results are qualitatively similarly if we omit these 91 deals.

Relative deal size: Alexandridis et al (2013) argue that the deal size (relative to that of the acquirer) can significantly influence acquirer returns and can at least partially explain the size effect in acquisitions. We mitigate this concern by controlling for relative deal size in the reported results. In addition, in untabulated robustness tests, we split the sample into the top $50 \%$ and bottom $50 \%$ in terms of relative deal size. We find similar results to the reported results in both the high relative-deal-size and low relative-deal-size subsamples, suggesting that relative-deal-size does not drive our results. 


\section{Conclusion}

This study examines the relationship between the acquirer size effect and sovereign governance. Prior literature from developed markets has generally focused on firm size as a source of agency conflicts and value destruction. However, large size could provide some off-setting benefits in weak governance environments. These benefits might derive from political connections and market power. They might also derive from larger size offering some protection from regimes that are affected by corruption at the government level.

We show that in weak governance markets, large firms' acquisitions earn significantly higher announcement returns, and are more likely to increase operating performance than they are in strong governance markets. We provide some evidence on the sources of these gains, including some evidence that larger firms in weak governance markets (compared with those in strong governance countries) tend to complete deals faster and tend to be more likely to do friendly deals. We also find evidence suggesting that at least part of the benefits of large size result from political connections. We take steps to ensure the results are robust to potential alternative explanations and model specification issues.

The results also help to explain why large acquirers earn lower takeover returns in strong governance environments, where size may give rise to potential entrenchment problems and agency conflicts. In these environments, regulatory strength effaces the political and protective benefit of being a large firm. This means that large size is relatively less useful as a protective mechanism in these markets. Thus, large size begins to reduce shareholder wealth due to possible agency and other conflicts.

The results also provide useful avenues for future research. Future studies could analyze other corporate and macroeconomic factors that moderate the size-effect in acquisitions. Additional research could also extend the analysis in Offenberg (2009) to examine the extent to which corporate size entrenches managers in weaker governance markets, potentially providing another explanation for the weaker-size effect documented in this study. 
Appendix 1

Table A1: Variable definitions

\begin{tabular}{|c|c|}
\hline Variable & Definition \\
\hline \multicolumn{2}{|l|}{ Bidder characteristics } \\
\hline CARs & $\begin{array}{l}\text { 11-day cumulative abnormal returns }(\%) \text {, calculated using the market } \\
\text { model, and the market-adjusted model. The paper estimates market model } \\
\text { parameters over days }(-210,-11) \text { using an OLS model. We obtain the } \\
\text { financial data from Datastream. }\end{array}$ \\
\hline Firm size measures & $\begin{array}{l}\text { Log of total assets; Log of market value (number of shares outstanding } \mathrm{x} \\
\text { price } 11 \text { days prior to announcement) }\end{array}$ \\
\hline Leverage & Book value of debt scaled by total assets \\
\hline Tobin's q & $\begin{array}{l}\text { Market value of assets scaled by book value of assets. The market value of } \\
\text { assets is the firm's market capitalization plus its book assets less its book } \\
\text { equity. }\end{array}$ \\
\hline CAPEX & The firm's capital expenditure (CAPEX) scaled by its sales \\
\hline Return on assets & $\begin{array}{l}\text { The return on assets is the firm's operating income scaled by its book } \\
\text { assets. }\end{array}$ \\
\hline Cash-holdings & The firm's cash holdings scaled by its book assets. \\
\hline \multicolumn{2}{|l|}{ Deal characteristics } \\
\hline Public target & Dummy: 1 for public targets, 0 otherwise \\
\hline Private target & Dummy: 1 for private targets, 0 otherwise \\
\hline Cash only & Dummy: 1 for deals financed with cash only, 0 otherwise \\
\hline Stock only & Dummy: 1 for deals financed with stock only, 0 otherwise \\
\hline Diversifying & $\begin{array}{l}\text { Dummy: } 1 \text { where bidder and target are in a different Fama-French } \\
\text { industry, } 0 \text { otherwise }\end{array}$ \\
\hline Relative size & $\begin{array}{l}\text { Transaction value over bidder's market capitalization } 11 \text { days before the } \\
\text { announcement date. }\end{array}$ \\
\hline Friendly & Dummy: 1 for deals recommended by target management, 0 otherwise \\
\hline Competed & Dummy: 1 for competed deals, 0 otherwise \\
\hline Tender offer & Dummy: 1 for tender offer deals, 0 otherwise \\
\hline Cross-border & Dummy: 1 for cross-border deals \\
\hline Approval (days to completion) & $\begin{array}{l}\text { Number of days from the takeover announcement date to the takeover } \\
\text { completion date }\end{array}$ \\
\hline Takeover premium & $\begin{array}{l}\text { Transaction value scaled by the target's market value } 1 \text { or } 4 \text { weeks prior to } \\
\text { takeover announcement minus } 1\end{array}$ \\
\hline
\end{tabular}

Country governance-type character
$\%$ Firms with MP/HOS or
relative thereof
$\%$ Firms with MP/HOS
$\%$ Top 50 Firms with MP/HOS
or relative thereof

ICRG Political Index

The percentage of firms in the country that have a member-ofparliament/politician or a head-of-state (or a relative thereof) on their board. The data is from Faccio (2006).

The percentage of firms in the country that have a member-ofparliament/politician or a head-of-state on their board. The data is from Faccio (2006).

The percentage of the top 50 firms in the country that have a member-ofparliament/politician or a head-of-state on their board. The data is from Faccio (2006).

The ICRG political risk index. The original index goes from 0 to 20 . We normalize the index to range from 0 to 1 . A higher score indicates better governance.

WB Gov Index The World Bank governance index is based on six World Bank governance sub-variables. The six World Bank variables are percentile ranks in terms of accountability, government effectiveness, political stability, regulation, the rule of law, and corruption. We compute a composite governance index 
(WB governance index), which is the equally weighted average of these six percentile ranks. The governance index ranges from 0 to 1 with a higher score representing better governance.

Country characteristics (sourced from the World Bank)

Home market capitalization (\%) Market capitalization of listed companies/GDP

Home stock turnover (\%) Total value of shares traded/Average market capitalization

FDI (\%)

Unemployment (\%)

Net inflows of investment / GDP

Trade Imbalance

$\%$ of labor force without work

(imports - exports)/(imports + exports) 


\section{References}

Ahern, K.R., Harford, J. Forthcoming. The Importance of Industry Links in Merger Waves. Journal of Finance.

Alexandridis, G., Fuller, K.P., Terhaar, L., Travlos, N.G. 2013. Deal Size, Acquisition Premia and Shareholder Gains. Journal of Corporate Finance , 20(1), 1-13.

Andrade, G., Mitchell, N., Stafford, E. 2001. New evidence and perspectives on mergers. Journal of Economic Perspectives , 15, 103-120.

Apodaca, C. 2004. The rule of law and human rights. Juridacature , 87(6), 292-299.

Baumol, W.J. 1962. On the Theory of Expansion of the Firm. American Economic Review , 52(5), 1078-1087.

Beasley, M.S. 1996. An Empirical Analysis of the Relation between the Board of Director Composition and Financial Statement Fraud. The Accounting Review , 71(4), 443-465.

Becker, C.L., DeFond, M.L., Jiambalvo, J., Subramanyam, K.R. 1998. The Effect of Audit Quality on Earnings Management. Contemporary Accounting Research , 15(1), 1-24.

Boone, A.L., Mulherin, J.H. 2008. Do auctions induce a winner's curse? New evidence from the corporate takeover market. Journal of Financial Economics , 89(1), 1-19.

Braun, M., Di Tella, R. 2004. Inflation, Inflation Variability, and Corruption. Economics \& Politics, 16, 77-100.

Brockman, P., Rui, O.M., Zou, H. 2013. Institutions and the performance of politically connected M\&As. Journal of International Business Studies , 44(8), 833-852.

Chang, J., Hong, J. 2000. Economic Performance of Group-Affiliated Companies in Korea: Intragroup Resource Sharing and Internal Business Transactions. Academy of Management Journal , 43(3), 429-448.

Chang, S. 1998. Takeovers of privately held targets, method of payment, and bidder returns. Journal of Finance, 53(2), 773-784.

Chen, C.J.P., Ding, Y., Kim, C. 2010. High-level politically connected firms, corruption, and analyst forecast accuracy around the world. Journal of International Business Studies , 41(9), 1505-1524.

Chen, D. 2013. Developing a Stock Market Without Institutions - The China Puzzle. Journal of Corporate Law Studies , 13(1), 151-184.

Chtourou, S.M., Bedard, J., Courteau, L. 2001. Corporate Governance and Earnings Management. Working Paper.

Coates, J.C. 2012. Corporate Politics, Governance, and Value Before and After Citizens United. Journal of Empirical Legal Studies , 9(4), 657-696.

D’Aveni, R.A., Kesner, I.F. 1993. Top Managerial Prestige, Power and Tender Offer Response: A Study of Elite Social Networks and Target Firm Cooperation during Takeovers. Organization Science , 4(2), 123-151.

Dechow, P.M., Dichev, I.D. 2002. The Quality of Accruals and Earnings: The Role of Accrual Estimation Errors. The Accounting Review , 77, 35-59.

Dechow, P.M., Sloan, R.G., Sweeney, A.P. 1995. Detecting Earnings Management. The Accounting Review , 70(2), 193-225.

Dimson, E. 1979. Risk measurement when shares are subject to infrequent trading. Journal of Financial Economics , 7(2), 197-226.

Dimson, E., Marsh, P.R. 1983. The Stability of UK Risk Measures and the Problem of Thin Trading. Journal of Finance, 38(3), 753-783.

Djankov, S., La Porta, R., Lopez-de-Silanes, F., Shleifer, A. 2008. The Law and Economics of Self-Dealing. Journal of Financial Economics , 88(3), 430-465.

Dollar, D., Kraay, A. 2003. Institutions, trade and growth. Journal of Monetary Economics , 50(1), 133-162.

Ellis, P.D. 2011. Social ties and international entrepreneurship: Opportunities and constraints affecting firm internationalization. Journal of International Business Studies , 42, 99-127.

Faccio, M. 2006. Politically Connected Firms. American Economic Review , 96(1), 369-386.

Faccio, M. 2010. Differences between politically connected and non-connected firms: A cross country analysis. Financial Management, 39(3), 905-927.

Faccio, M., Masulis, R.W., McConnell, J.J. 2006. Political Connections and Corporate Bailouts. Journal of Finance, 61(6), 2597-2635. 
Fan, J.P.H., Huang, J., Oberholzer-Gee, F., Smith, T.D., Zhao, M. 2008. Diversification of Chinese companies: An international comparison. Chinese Management Studies , 2(1), 6-13.

Farina, E.M.M.Q. 2002. Consolidation, Multinationalisation, and Competition in Brazil: Impacts on Horticulture and Dairy Products Systems. Development Policy Review , 20(4), 441-457.

Fisman, R. 2001. Estimating the Value of Political Connections. American Economic Review , 91(4), 10951102.

Fuller, K., Netter, J., Stegemoller, M. 2002. What do returns to acquiring firms tell us? Evidence from firms that make many acquisitions. Journal of Finance , 57(4), 1763-1794.

Giliberto, S.M., Varaiya, N.P. 1989. The Winner's Curse and Bidder Competition in Acquisitions: Evidence from Failed Bank Auctions. Journal of Finance , 44(1), 59-75.

Granovetter, M. 1995. Coase Revisited: Business Groups in the Modern Economy. Industrial and Corporate Change, 4(1), 93-130.

Guiso, L., Rustichini, A. 2011. Understanding the size and profitability of firms: The role of a biological factor (Discussion Paper No. DP8205). CEPR.

Harford, J., Humphery-Jenner, M.L., Powell, R.G. 2012. The Sources of Value Destruction in Acquisitions by Entrenched Managers. Journal of Financial Economics , 106(2), 247-261.

He, J., Mao, X., Rui, O.M., Zha, X. 2013. Business groups in China. Journal of Corporate Finance , 22, 166192.

He, X., Su, Y. 2013. Do the "Haves" Come Out Ahead in Shanghai Courts? Journal of Empirical Legal Studies , 10(1), 120-145.

Healy, P., Palepu, K., Ruback, R. 1992. Does corporate performance improve after mergers? Journal of Financial Economics , 31, 135-175.

Humphery-Jenner, M., Powell, R.G. 2011. Firm size, takeover profitability and the effectiveness of the market for corporate control: Does the absence of anti-takeover provisions make a difference? Journal of Corporate Finance, 17(3), 418-437.

Jensen, M., Ruback, R.S. 1983. The market for corporate control: the scientific evidence. Journal of Financial Economics , 11, 5-50.

Jensen, M.C. 1986. Agency costs of free cash flow, corporate finance, and takeovers. American Economic Review , 76(2), 323-329.

Johnson, S., Mitton, T. 2003. Cronyism and capital controls: evidence from Malaysia. Journal of Financial Economics, 67(2), 351-382.

Jones, J. 1991. Earnings management during import relief investigations. Journal of Accounting Research, 29, $193-228$.

Khanna, T. 2000. Business groups and social welfare in emerging markets: Existing evidence and unanswered questions. European Economic Review , 44(4-6), 748-761.

Khanna, T., Palepu, K. 2000. The Future of Business Groups in Emerging Markets: Long-Run Evidence from Chile. Academy of Management Journal , 43(3), 268-285.

Khanna, T., Yafeh, Y. 2007. Business Groups in Emerging Markets: Paragons or Parasites? Journal of Economic Literature , 45(2), 331-372.

Krishnan, C.N.V., Masulis, R.W., Thomas, R.S., Thompson, R.B. 2012. Shareholder litigation in Mergers and Acquisitions. Journal of Corporate Finance , 18(5), 1248-1268.

Krishnan, C.V.N., Masulis, R. 2013. Law Firm Expertise and Mergers and Acquisitions. Journal of Law and Economics Forthcoming.

Li, X. 2013. Productivity, restructuring, and the gains from takeovers. Journal of Financial Economics , 109(1), 250-271.

Lucas, R. 1978. On the Size Distribution of Business Firms. Bell Journal of Economics , 9(2), 508-523.

MacIntyre, A. 2003. Institutions and the Political Economy of Corruption in Developing Countries (Discussion Paper), Workshop on Corruption. Stanford University.

Masulis, R.W., Mobbs, H.S. Forthcoming. Independent Director Incentives: Where do Talented Directors Spend Their Time and Energy? Journal of Finance. 
Masulis, R.W., Wang, C., Xie, F. 2007. Corporate Governance and Acquirer Returns. Journal of Finance , 62(4), 1851-1889.

Menkhoff, L., Neuberger, D., Suwanaporn, C. 2006. Collateral-based lending in emerging markets: Evidence from Thailand. Journal of Banking \& Finance , 30(1), 1-21.

Moeller, S.B., Schlingemann, F.P., Stulz, R.M. 2004. Firm size and the gains from acquisitions. Journal of Financial Economics , 73(2), 201-228.

Moeller, S.B., Schlingemann, F.P., Stulz, R.M. 2005. Wealth Destruction on a Massive Scale? A Study of Acquiring-Firm Returns in the Recent Merger Wave. Journal of Finance , 60(2), 757-782.

Neumayer, E. 2002. Do democracies exhibit stronger international environmental commitment? A cross-country analysis. Journal of Peace Research , 39(2), 139-164.

Offenberg, D. 2009. Firm size and the effectiveness of the market for corporate control. Journal of Corporate Finance, 15(1), 66-79.

Petersen, M.A. 2009. Estimating Standard Errors in Finance Panel Data Sets: Comparing Approaches. Review of Financial Studies , 22(1), 435-480.

La Porta, R., Lopez-de-Silanes, F., Shleifer, A., Vishny, R.W. 1997. Legal Determinants of External Finance. Journal of Finance, 52(3), 1131-1150.

Powell, R.G., Stark, A.W. 2005. Does operating performance increase post-takeover for UK takeovers? A comparison of performance measures and benchmarks. Journal of Corporate Finance , 11(1-2), 293317.

Powell, R.G., Yawson, A. 2005. Industry aspects of takeovers and divestitures: evidence from the UK. Journal of Banking \& Finance , 29(12), 3015-3040.

Roy, J.-P., Oliver, C. 2009. International joint venture partner selection: The role of the host-country legal environment. Journal of International Business Studies , 40, 779-801.

Scharfstein, D. 1988. The Disciplinary Role of Takeovers. Review of Economic Studies , 55(2), 185-199.

Scholes, M., Williams, J. 1977. Estimating betas from nonsynchronous data. Journal of Financial Economics, 5(3), 309-327.

Shleifer, A., Vishny, R.W. 1989. Management Entrenchment: The Case of Manager-Specific Investments. Journal of Financial Economics , 25(1), 123-139.

Spamann, H. 2010. The "Antidirector Rights Index" Revisited. Review of Financial Studies , 23(2), 467-486.

Thomas, M.A. 2010. What Do the Worldwide Governance Indicators Measure? European Journal of Development Research, 22, 31-54.

Travlos, N. 1987. Corporate takeover bids, method of payment, and bidding firms' stock returns. Journal of Finance, 52, 943-963.

Volkov, V. 2004. Hostile Enterprise Takeovers: Russia's Economy in 1998-2002. Review of Central and East European Law , 29(4), 527-548.

Zheng, W., Singh, K. 2010. Interlocking Political Ties and Firm Acquisition During Institutional Transition (Working Paper).

Zhiang, L., Peng, M.W., Yang, H., Sun, S.L. 2009. How do networks and learning drive M\&As? An institutional comparison between China and the United States. Strategic Management Journal , 30(10), 1113-1132. 


\section{Table 1}

\section{Summary statistics by year}

This table reports mean sample statistics by year. The term \%CAR is the 11-day CAR in percentage terms, measured from 5 days before the takeover announcement date to 5 days after. MAM and MM denote abnormal returns calculated using a market-adjusted model and a market model, respectively. The variable $\$ C A R$ is the 11-day dollar car inflated to US\$m 2009. Market capitalization and assets inflated to US\$2009, and are reported in millions.

\begin{tabular}{cccccccc}
\hline Year & $\begin{array}{c}\text { No. } \\
\text { Observations }\end{array}$ & $\begin{array}{c}\text { \%CAR } \\
\text { MAM }\end{array}$ & $\begin{array}{c}\text { \%CAR } \\
\text { MM }\end{array}$ & $\begin{array}{c}\text { \$CAR } \\
\text { MAM }\end{array}$ & $\begin{array}{c}\text { \$CAR } \\
\text { MM }\end{array}$ & $\begin{array}{c}\text { Market } \\
\text { Capitalization }\end{array}$ & Assets \\
\hline 1996 & 1,023 & 1.757 & 1.895 & 13.287 & 12.934 & 2,014 & 1,566 \\
1997 & 1,517 & 1.417 & 1.444 & -6.142 & -4.688 & 3,028 & 1,820 \\
1998 & 1,879 & 1.140 & 1.582 & 6.068 & 5.489 & 3,184 & 2,180 \\
1999 & 1,462 & 1.264 & 1.441 & 2.517 & -3.380 & 9,322 & 3,552 \\
2000 & 1,568 & 0.254 & 1.301 & -51.301 & -48.040 & 11,869 & 3,671 \\
2001 & 915 & -0.094 & 1.786 & -18.106 & -21.452 & 7,801 & 2,702 \\
2002 & 963 & 0.201 & 1.963 & 1.660 & 22.257 & 2,789 & 2,209 \\
2003 & 984 & 2.063 & 2.821 & -5.909 & 5.858 & 4,121 & 2,413 \\
2004 & 1,359 & 1.807 & 2.073 & -9.443 & -6.619 & 12,987 & 2,391 \\
2005 & 1,556 & 2.080 & 2.152 & 10.136 & 7.768 & 4,935 & 3,498 \\
2006 & 1,630 & 1.927 & 2.215 & -0.971 & -2.267 & 4,216 & 3,272 \\
2007 & 1,672 & 1.747 & 2.546 & 20.309 & 23.297 & 4,293 & 3,724 \\
2008 & 1,119 & 0.737 & 2.103 & -7.643 & -3.738 & 3,329 & 2,665 \\
\hline Total & 17,647 & 1.306 & 1.923 & -1.647 & 0.395 & 5,647 & 2,812 \\
\hline
\end{tabular}


Table 2

Summary statistics for model variables

The table reports summary statistics for CARs, governance, acquirer, deal, and country-level characteristics for the pooled sample. Detailed variable definitions are reported in appendix 1 (Table A1).

\begin{tabular}{|c|c|c|c|c|}
\hline Variable & Mean & Median & $\begin{array}{c}\text { Standard } \\
\text { Deviation }\end{array}$ & $\begin{array}{c}\text { Number of } \\
\text { Obs. }\end{array}$ \\
\hline \multicolumn{5}{|l|}{ Panel A: Governance indices } \\
\hline WB Governance index & 0.888 & 0.909 & 0.082 & 17,647 \\
\hline ICRG Political index & 0.844 & 0.855 & 0.050 & 17,459 \\
\hline \multicolumn{5}{|c|}{ Panel B: Acquirer financial and deal characteristics } \\
\hline \%CAR (Market-adjusted model, MAM) & 1.306 & 0.778 & 8.228 & 17,647 \\
\hline \%CAR (Market model, MM) & 1.923 & 0.895 & 7.949 & 17,647 \\
\hline \$CAR (MAM, US\$m, 2009) & -1.647 & 1.265 & 296.713 & 14,582 \\
\hline \$CAR (MM, US\$m, 2009)) & 0.395 & 1.435 & 287.772 & 14,582 \\
\hline Market capitalization (US\$m, 2009) & 5,647 & 478 & 95,828 & 14,582 \\
\hline Assets (US\$m, 2009) & 2,812 & 441 & 11,670 & 17,647 \\
\hline Relative size & 0.238 & 0.083 & 0.457 & 17,647 \\
\hline Return on assets & 0.082 & 0.110 & 0.180 & 17,647 \\
\hline Leverage (market) & 0.175 & 0.134 & 0.168 & 17,647 \\
\hline Cash-holdings & 0.145 & 0.075 & 0.174 & 17,647 \\
\hline CAPEX & 0.065 & 0.038 & 0.082 & 17,647 \\
\hline Diversifying deal & 0.672 & 1 & 0.470 & 17,647 \\
\hline Competed & 0.008 & 0 & 0.086 & 17,647 \\
\hline Tender offer & 0.044 & 0 & 0.205 & 17,647 \\
\hline Friendly & 0.985 & 1 & 0.123 & 17,647 \\
\hline Cross-border & 0.259 & 0 & 0.438 & 17,647 \\
\hline Cash only & 0.260 & 0 & 0.439 & 17,647 \\
\hline Stock only & 0.140 & 0 & 0.347 & 17,647 \\
\hline Mixed & 0.600 & 1 & 0.490 & 17,647 \\
\hline Public & 0.126 & 0 & 0.332 & 17,647 \\
\hline Private & 0.528 & 1 & 0.499 & 17,647 \\
\hline Subsidiary & 0.346 & 0 & 0.476 & 17,647 \\
\hline Days to completion & 52.54 & 27 & 75.37 & 17,646 \\
\hline \multicolumn{5}{|c|}{ Panel C: Country-level financial characteristics } \\
\hline Home market capitalization (\%) & 1.309 & 1.371 & 0.444 & 17,647 \\
\hline Home stock turnover $(\%)$ & 106.213 & 103.200 & 47.223 & 17,647 \\
\hline FDI (\%) & 0.028 & 0.020 & 0.049 & 17,647 \\
\hline Unemployment (\%) & 5.656 & 5.200 & 2.011 & 17,647 \\
\hline Trade Imbalance & 5.271 & 5.477 & 8.773 & 17,647 \\
\hline
\end{tabular}


Table 3

Summary statistics for CARs and country-governance by country

\begin{tabular}{|c|c|c|c|c|c|c|c|c|c|c|}
\hline Acq. Nation & Obs. & CAR & $\begin{array}{c}\text { WB Gov } \\
\text { Accountability }\end{array}$ & $\begin{array}{l}\text { WB Gov } \\
\text { Anti- } \\
\text { corruption }\end{array}$ & $\begin{array}{c}\text { WB Gov } \\
\text { Effectiveness }\end{array}$ & $\begin{array}{l}\text { WB Gov } \\
\text { Political } \\
\text { Stability }\end{array}$ & $\begin{array}{c}\text { WB Gov } \\
\text { Regulation }\end{array}$ & $\begin{array}{c}\text { WB Gov } \\
\text { Rule of } \\
\text { Law }\end{array}$ & $\begin{array}{c}\text { WB } \\
\text { Gov } \\
\text { Index }\end{array}$ & $\begin{array}{c}\text { ICRG } \\
\text { Political } \\
\text { Index }\end{array}$ \\
\hline Argentina & 6 & 2.734 & 0.575 & 0.424 & 0.530 & 0.486 & 0.236 & 0.387 & 0.439 & 0.697 \\
\hline Australia & 1405 & 3.393 & 0.943 & 0.948 & 0.956 & 0.820 & 0.956 & 0.954 & 0.929 & 0.872 \\
\hline Austria & 28 & 0.832 & 0.923 & 0.947 & 0.932 & 0.881 & 0.939 & 0.970 & 0.932 & 0.866 \\
\hline Belgium & 57 & 2.353 & 0.935 & 0.909 & 0.925 & 0.766 & 0.899 & 0.904 & 0.890 & 0.832 \\
\hline Brazil & 67 & 0.158 & 0.605 & 0.559 & 0.532 & 0.390 & 0.558 & 0.450 & 0.516 & 0.662 \\
\hline Chile & 10 & 4.113 & 0.805 & 0.888 & 0.869 & 0.732 & 0.910 & 0.865 & 0.845 & 0.780 \\
\hline China & 91 & 4.743 & 0.057 & 0.376 & 0.608 & 0.342 & 0.444 & 0.436 & 0.377 & 0.686 \\
\hline Colombia & 1 & -3.727 & 0.394 & 0.539 & 0.536 & 0.048 & 0.546 & 0.305 & 0.395 & 0.580 \\
\hline Denmark & 61 & 3.650 & 0.986 & 0.986 & 0.990 & 0.843 & 0.980 & 0.987 & 0.962 & 0.871 \\
\hline Finland & 115 & 1.399 & 0.988 & 0.998 & 0.981 & 0.988 & 0.975 & 0.984 & 0.986 & 0.934 \\
\hline France & 269 & 1.789 & 0.887 & 0.906 & 0.900 & 0.683 & 0.838 & 0.899 & 0.852 & 0.782 \\
\hline Germany & 165 & 0.380 & 0.928 & 0.940 & 0.931 & 0.851 & 0.924 & 0.936 & 0.918 & . \\
\hline Greece & 11 & 2.564 & 0.766 & 0.648 & 0.721 & 0.621 & 0.756 & 0.729 & 0.707 & 0.767 \\
\hline Hungary & 1 & -4.462 & 0.875 & 0.718 & 0.754 & 0.764 & 0.844 & 0.733 & 0.781 & 0.815 \\
\hline Iceland & 8 & 0.214 & 0.976 & 0.996 & 0.989 & 1.000 & 0.957 & 1.000 & 0.986 & 0.905 \\
\hline India & 37 & 0.466 & 0.608 & 0.451 & 0.517 & 0.228 & 0.442 & 0.584 & 0.472 & 0.616 \\
\hline Indonesia & 5 & 9.585 & 0.430 & 0.266 & 0.439 & 0.133 & 0.396 & 0.269 & 0.322 & 0.576 \\
\hline Ireland-Rep & 138 & 0.496 & 0.929 & 0.920 & 0.918 & 0.908 & 0.971 & 0.930 & 0.929 & 0.893 \\
\hline Israel & 61 & 1.284 & 0.682 & 0.820 & 0.839 & 0.131 & 0.806 & 0.772 & 0.675 & 0.628 \\
\hline Italy & 93 & 1.687 & 0.799 & 0.690 & 0.735 & 0.636 & 0.776 & 0.683 & 0.720 & 0.788 \\
\hline Japan & 597 & 1.853 & 0.779 & 0.860 & 0.875 & 0.847 & 0.812 & 0.892 & 0.844 & 0.826 \\
\hline Jersey & 1 & -18.279 & 0.928 & 0.937 & 0.943 & 0.673 & 0.981 & 0.924 & 0.898 & 0.830 \\
\hline Luxembourg & 3 & 3.439 & 0.960 & 0.940 & 0.946 & 0.989 & 0.987 & 0.970 & 0.965 & 0.930 \\
\hline Malaysia & 188 & 1.251 & 0.373 & 0.661 & 0.801 & 0.561 & 0.666 & 0.643 & 0.618 & 0.733 \\
\hline Mexico & 25 & 0.298 & 0.528 & 0.474 & 0.615 & 0.351 & 0.641 & 0.401 & 0.502 & 0.723 \\
\hline Netherlands & 125 & 1.395 & 0.985 & 0.972 & 0.970 & 0.867 & 0.977 & 0.948 & 0.953 & 0.887 \\
\hline New Zealand & 66 & 1.820 & 0.982 & 0.988 & 0.944 & 0.955 & 0.964 & 0.969 & 0.967 & 0.886 \\
\hline Norway & 129 & 3.417 & 0.980 & 0.958 & 0.975 & 0.940 & 0.906 & 0.991 & 0.958 & 0.884 \\
\hline Peru & 4 & 5.433 & 0.494 & 0.487 & 0.371 & 0.191 & 0.579 & 0.282 & 0.401 & 0.628 \\
\hline Portugal & 13 & 3.224 & 0.906 & 0.840 & 0.814 & 0.832 & 0.842 & 0.837 & 0.845 & 0.844 \\
\hline Russian Fed & 23 & -3.625 & 0.226 & 0.183 & 0.432 & 0.228 & 0.327 & 0.189 & 0.264 & . \\
\hline Singapore & 136 & 2.024 & 0.479 & 0.980 & 0.994 & 0.899 & 0.992 & 0.929 & 0.879 & 0.856 \\
\hline South Africa & 76 & 3.604 & 0.713 & 0.685 & 0.772 & 0.340 & 0.648 & 0.566 & 0.621 & 0.679 \\
\hline South Korea & 93 & 3.583 & 0.672 & 0.689 & 0.844 & 0.595 & 0.732 & 0.751 & 0.714 & 0.766 \\
\hline Spain & 87 & 1.629 & 0.859 & 0.864 & 0.849 & 0.554 & 0.865 & 0.851 & 0.807 & 0.799 \\
\hline Sweden & 245 & 2.485 & 0.973 & 0.979 & 0.975 & 0.928 & 0.939 & 0.973 & 0.961 & 0.895 \\
\hline Switzerland & 84 & 2.693 & 0.956 & 0.966 & 0.989 & 0.979 & 0.944 & 0.990 & 0.971 & 0.889 \\
\hline Thailand & 25 & 1.299 & 0.506 & 0.497 & 0.637 & 0.372 & 0.608 & 0.563 & 0.530 & 0.671 \\
\hline Turkey & 2 & -8.559 & 0.416 & 0.601 & 0.632 & 0.211 & 0.593 & 0.547 & 0.500 & 0.630 \\
\hline $\begin{array}{l}\text { United } \\
\text { Kingdom }\end{array}$ & 3207 & 1.865 & 0.899 & 0.954 & 0.947 & 0.722 & 0.976 & 0.944 & 0.907 & 0.861 \\
\hline United States & 8456 & 0.951 & 0.900 & 0.922 & 0.932 & 0.750 & 0.942 & 0.927 & 0.896 & 0.843 \\
\hline Total & 17647 & 1.306 & 0.883 & 0.916 & 0.927 & 0.757 & 0.928 & 0.917 & 0.888 & 0.844 \\
\hline
\end{tabular}




\section{Table 4}

\section{CARs by governance and size tercile, quartile, and quintile}

This table contains the mean and median acquirer CAR split by size and World Bank governance tercile, quartile, or quintile. The CARs are market-adjusted model acquirer CARs computed over the 11-day window surrounding the acquisition announcement.

\begin{tabular}{|c|c|c|c|c|c|c|c|c|c|c|c|}
\hline & Mean & Median & $\mathrm{N}$ & & Mean & Median & $\mathrm{N}$ & & Mean & Median & $\mathrm{N}$ \\
\hline Assets Tercile 3 & & & & Assets Quartile 4 & & & & Assets Quintile 5 & & & \\
\hline Gov Tercile 1 & 0.756 & 0.466 & 2451 & Gov Quartile 1 & 0.633 & 0.379 & 1525 & Gov Quintile 1 & 0.497 & 0.315 & 1052 \\
\hline Gov Tercile 2 & 0.277 & 0.131 & 2239 & Gov Quartile 2 & 0.733 & 0.420 & 1143 & Gov Quintile 2 & 0.804 & 0.688 & 655 \\
\hline Gov Tercile 3 & 0.080 & 0.082 & 1192 & Gov Quartile 3 & -0.212 & -0.145 & 866 & Gov Quintile 3 & -0.536 & -0.384 & 805 \\
\hline \multirow[t]{3}{*}{ Overall } & 0.437 & 0.333 & 5882 & Gov Quartile 4 & 0.106 & 0.072 & 877 & Gov Quintile 4 & -0.100 & -0.161 & 431 \\
\hline & & & & Overall & 0.388 & 0.240 & 4411 & Gov Quintile 5 & 0.200 & 0.496 & 584 \\
\hline & & & & & & & & Overall & 0.196 & 0.140 & 3527 \\
\hline $\begin{array}{l}\text { Gov Tercile } 1 \\
\text { - Gov Tercile } 3\end{array}$ & $0.676^{* *}$ & $0.383 * * *$ & & $\begin{array}{l}\text { Gov Quartile } 1 \\
\text { - Gov Quartile } 4\end{array}$ & $0.527^{*}$ & $0.307 * * *$ & & $\begin{array}{l}\text { Gov Quintile } 1 \\
\text { - Gov Quintile } 5\end{array}$ & $0.297 * *$ & $-0.181 * * *$ & \\
\hline Assets Tercile 2 & & & & Assets Quartile 3 & & & & Assets Quintile 4 & & & \\
\hline Gov Tercile 1 & 1.569 & 1.139 & 1985 & Gov Quartile 1 & 1.372 & 0.862 & 1230 & Gov Quintile 1 & 1.386 & 0.733 & 849 \\
\hline Gov Tercile 2 & 1.395 & 0.853 & 2563 & Gov Quartile 2 & 1.207 & 0.816 & 1255 & Gov Quintile 2 & 1.126 & 0.810 & 661 \\
\hline Gov Tercile 3 & 0.543 & 0.445 & 1334 & Gov Quartile 3 & 1.100 & 0.514 & 1026 & Gov Quintile 3 & 0.800 & 0.550 & 799 \\
\hline \multirow[t]{3}{*}{ Overall } & 1.260 & 0.908 & 5882 & Gov Quartile 4 & -0.003 & 0.009 & 898 & Gov Quintile 4 & 0.877 & 0.329 & 613 \\
\hline & & & & Overall & 0.982 & 0.643 & 4409 & Gov Quintile 5 & -0.006 & -0.048 & 609 \\
\hline & & & & & & & & Overall & 0.876 & 0.568 & 3531 \\
\hline $\begin{array}{l}\text { Gov Tercile } 1 \\
\text { - Gov Tercile } 3\end{array}$ & 1.026 & 0.694 & & $\begin{array}{l}\text { Gov Quartile } 1 \\
\text { - Gov Quartile } 4\end{array}$ & 1.375 & 0.853 & & $\begin{array}{l}\text { Gov Quintile } 1 \\
\text { - Gov Quintile } 5\end{array}$ & 1.392 & 0.781 & \\
\hline Assets Tercile 1 & & & & Assets Quartile 2 & & & & Assets Quintile 3 & & & \\
\hline Gov Tercile 1 & 2.507 & 1.611 & 1638 & Gov Quartile 1 & 1.431 & 1.004 & 1063 & Gov Quintile 1 & 1.540 & 0.963 & 756 \\
\hline Gov Tercile 2 & 1.846 & 1.022 & 2229 & Gov Quartile 2 & 1.545 & 1.095 & 1314 & Gov Quintile 2 & 1.722 & 1.210 & 675 \\
\hline Gov Tercile 3 & 2.403 & 2.187 & 2016 & Gov Quartile 3 & 2.006 & 1.291 & 962 & Gov Quintile 3 & 1.162 & 0.912 & 840 \\
\hline \multirow[t]{3}{*}{ Overall } & 2.221 & 1.481 & 5883 & Gov Quartile 4 & 1.262 & 1.086 & 1076 & Gov Quintile 4 & 1.485 & 0.838 & 650 \\
\hline & & & & Overall & 1.549 & 1.110 & 4415 & Gov Quintile 5 & 0.320 & 0.408 & 609 \\
\hline & & & & & & & & Overall & 1.264 & 0.928 & 3530 \\
\hline \multirow[t]{17}{*}{$\begin{array}{l}\text { Gov Tercile } 1 \\
\text { - Gov Tercile } 3\end{array}$} & $0.104 * * *$ & $-0.576^{* *}$ & & $\begin{array}{l}\text { Gov Quartile } 1 \\
\text { - Gov Quartile } 4\end{array}$ & 0.170 & -0.082 & & $\begin{array}{l}\text { Gov Quintile } 1 \\
\text { - Gov Quintile } 5\end{array}$ & 1.221 & 0.555 & \\
\hline & & & & Assets Quartile 1 & & & & Assets Quintile 2 & & & \\
\hline & & & & Gov Quartile 1 & 2.481 & 1.352 & 721 & Gov Quintile 1 & 1.983 & 1.136 & 656 \\
\hline & & & & Gov Quartile 2 & 2.150 & 1.337 & 1332 & Gov Quintile 2 & 2.167 & 2.010 & 717 \\
\hline & & & & Gov Quartile 3 & 2.292 & 1.344 & 854 & Gov Quintile 3 & 0.729 & 0.271 & 705 \\
\hline & & & & Gov Quartile 4 & 2.366 & 2.365 & 1505 & Gov Quintile 4 & 2.578 & 1.874 & 717 \\
\hline & & & & Overall & 2.305 & 1.556 & 4412 & Gov Quintile 5 & 1.673 & 1.680 & 734 \\
\hline & & & & & & & & Overall & 1.826 & 1.339 & 3529 \\
\hline & & & & $\begin{array}{l}\text { Gov Quartile } 1 \\
\text { - Gov Quartile } 4\end{array}$ & $0.115 * * *$ & -1.013 & & $\begin{array}{l}\text { Gov Quintile } 1 \\
\text { - Gov Quintile } 5\end{array}$ & $0.311^{*}$ & -0.543 & \\
\hline & & & & & & & & Assets Quintile 1 & & & \\
\hline & & & & & & & & Gov Quintile 1 & 2.248 & 1.396 & 435 \\
\hline & & & & & & & & Gov Quintile 2 & 2.557 & 1.586 & 800 \\
\hline & & & & & & & & Gov Quintile 3 & 2.321 & 1.415 & 606 \\
\hline & & & & & & & & Gov Quintile 4 & 1.975 & 1.275 & 712 \\
\hline & & & & & & & & Gov Quintile 5 & 2.581 & 2.379 & 977 \\
\hline & & & & & & & & Overall & 2.368 & 1.575 & 3530 \\
\hline & & & & & & & & $\begin{array}{l}\text { Gov Quintile } 1 \\
\text { - Gov Quintile } 5\end{array}$ & $-0.333 * *$ & -0.983 & \\
\hline
\end{tabular}


Table 5: Acquirer announcement returns (CARs) regressions

The table reports OLS regressions that examine the market's reaction to the firm's takeover decision. The dependent variable is the 11-day market-adjusted CAR. Detailed variable definitions are reported in appendix 1 . The models include year dummies (untabulated). $P$-values calculated using heteroskedasticityconsistent standard errors and corrected for industry-level clustering (using 4-digit SIC industry codes) are reported in parentheses. Superscripts ${ }^{* * *},{ }^{* *}$, and $*$, denote significance at $1 \%, 5 \%$, and $10 \%$, respectively.

\begin{tabular}{|c|c|c|c|c|c|c|c|c|}
\hline \multirow{2}{*}{$\begin{array}{l}\text { Dependent Variable } \\
\text { Variables }\end{array}$} & \multicolumn{8}{|c|}{ 11-day \%CAR } \\
\hline & {$[1]$} & {$[2]$} & [3] & [4] & [5] & {$[6]$} & [7] & {$[8]$} \\
\hline Ln(Assets) & $\begin{array}{c}0.059 \\
{[0.325]}\end{array}$ & $\begin{array}{c}0.057 \\
{[0.340]}\end{array}$ & $\begin{array}{c}0.290 * * * \\
{[0.000]}\end{array}$ & $\begin{array}{c}0.293 * * * \\
{[0.000]}\end{array}$ & & & & \\
\hline WB Gov Index & $\begin{array}{c}0.142 \\
{[0.914]}\end{array}$ & & $\begin{array}{c}5.016 * * * \\
{[0.003]}\end{array}$ & & & & & \\
\hline ICRG Political Index & & $\begin{array}{l}-0.582 \\
{[0.772]}\end{array}$ & & $\begin{array}{l}3.854 * \\
{[0.085]}\end{array}$ & & & & \\
\hline Ln(Assets)* WB Gov Index & & & $\begin{array}{c}-0.385 * * * \\
{[0.000]}\end{array}$ & & & & & \\
\hline Ln(Assets)* ICRG Political Index & & & & $\begin{array}{c}-0.409 * * * \\
{[0.000]}\end{array}$ & & & & \\
\hline Size top $25 \%$ & & & & & $\begin{array}{c}-1.228 * * * \\
{[0.000]}\end{array}$ & & $\begin{array}{c}-1.125 * * * \\
{[0.000]}\end{array}$ & \\
\hline Size top $10 \%$ & & & & & & $\begin{array}{c}-1.373 * * * \\
{[0.000]}\end{array}$ & & $\begin{array}{c}-1.277 * * * \\
{[0.000]}\end{array}$ \\
\hline Weak WB Gov x Size top $25 \%$ & & & & & $\begin{array}{c}0.658 * * \\
{[0.016]}\end{array}$ & & & \\
\hline Weak WB Gov x Size top $10 \%$ & & & & & & $\begin{array}{l}0.710^{*} \\
{[0.066]}\end{array}$ & & \\
\hline Weak Political Gov x Size top $25 \%$ & & & & & & & $\begin{array}{c}0.514 * * \\
{[0.034]}\end{array}$ & \\
\hline Weak Political Gov x Size top $10 \%$ & & & & & & & & $\begin{array}{c}0.612 \\
{[0.100]}\end{array}$ \\
\hline Weak WB Gov & & & & & $\begin{array}{l}-0.375 \\
{[0.115]}\end{array}$ & $\begin{array}{l}-0.284 \\
{[0.197]}\end{array}$ & & \\
\hline Weak Political Gov & & & & & & & $\begin{array}{c}0.043 \\
{[0.826]}\end{array}$ & $\begin{array}{c}0.103 \\
{[0.569]}\end{array}$ \\
\hline Tobin's q & $\begin{array}{c}0.262 * * * \\
{[0.000]}\end{array}$ & $\begin{array}{c}0.268 * * * \\
{[0.000]}\end{array}$ & $\begin{array}{c}0.266 * * * \\
{[0.000]}\end{array}$ & $\begin{array}{c}0.273 * * * \\
{[0.000]}\end{array}$ & $\begin{array}{c}0.265^{* * *} * \\
{[0.000]}\end{array}$ & $\begin{array}{c}0.264 * * * \\
{[0.000]}\end{array}$ & $\begin{array}{c}0.267 * * * \\
{[0.000]}\end{array}$ & $\begin{array}{c}0.265^{* * * *} \\
{[0.000]}\end{array}$ \\
\hline Relative size & $\begin{array}{c}1.156^{* * *} * \\
{[0.000]}\end{array}$ & $\begin{array}{c}1.155^{* * *} * \\
{[0.000]}\end{array}$ & $\begin{array}{c}0.872 * * * \\
{[0.002]}\end{array}$ & $\begin{array}{c}0.868 * * * \\
{[0.002]}\end{array}$ & $\begin{array}{c}1.045^{* * *} * \\
{[0.000]}\end{array}$ & $\begin{array}{c}1.085^{* * *} * \\
{[0.000]}\end{array}$ & $\begin{array}{c}1.047 * * * \\
{[0.000]}\end{array}$ & $\begin{array}{c}1.089 * * * \\
{[0.000]}\end{array}$ \\
\hline Return on assets & $\begin{array}{c}0.946 \\
{[0.112]}\end{array}$ & $\begin{array}{c}0.881 \\
{[0.139]}\end{array}$ & $\begin{array}{c}1.539 * * * \\
{[0.006]}\end{array}$ & $\begin{array}{c}1.475 * * * \\
{[0.009]}\end{array}$ & $\begin{array}{l}1.188 * * \\
{[0.048]}\end{array}$ & $\begin{array}{l}1.117 * \\
{[0.063]}\end{array}$ & $\begin{array}{l}1.151^{*} \\
{[0.058]}\end{array}$ & $\begin{array}{c}1.081^{*} \\
{[0.074]}\end{array}$ \\
\hline Leverage & $\begin{array}{c}-1.483 * * \\
{[0.014]}\end{array}$ & $\begin{array}{c}-1.532 * * \\
{[0.011]}\end{array}$ & $\begin{array}{l}-0.627 \\
{[0.289]}\end{array}$ & $\begin{array}{l}-0.661 \\
{[0.263]}\end{array}$ & $\begin{array}{l}-1.066^{*} \\
{[0.078]}\end{array}$ & $\begin{array}{c}-1.283 * * \\
{[0.034]}\end{array}$ & $\begin{array}{l}-1.119^{*} \\
{[0.062]}\end{array}$ & $\begin{array}{c}-1.336 * * \\
{[0.026]}\end{array}$ \\
\hline Cash-holdings & $\begin{array}{c}-1.073 * * \\
{[0.033]}\end{array}$ & $\begin{array}{c}-1.145^{* *} \\
{[0.032]}\end{array}$ & $\begin{array}{c}-1.537 * * * \\
{[0.001]}\end{array}$ & $\begin{array}{c}-1.602 * * * \\
{[0.002]}\end{array}$ & $\begin{array}{c}-1.230 * * \\
{[0.016]}\end{array}$ & $\begin{array}{c}-1.122^{* *} \\
{[0.027]}\end{array}$ & $\begin{array}{c}-1.266^{* *} \\
{[0.013]}\end{array}$ & $\begin{array}{c}-1.163 * * \\
{[0.022]}\end{array}$ \\
\hline CAPEX & $\begin{array}{c}-4.708 * * * \\
{[0.000]}\end{array}$ & $\begin{array}{c}-4.691 * * * \\
{[0.000]}\end{array}$ & $\begin{array}{c}-4.840 * * * \\
{[0.000]}\end{array}$ & $\begin{array}{c}-4.816^{* * * *} \\
{[0.000]}\end{array}$ & $\begin{array}{c}-5.004 * * * \\
{[0.000]}\end{array}$ & $\begin{array}{c}-4.955^{* * *} * \\
{[0.000]}\end{array}$ & $\begin{array}{c}-4.806 * * * * \\
{[0.000]}\end{array}$ & $\begin{array}{c}-4.797 * * * \\
{[0.000]}\end{array}$ \\
\hline Diversifying & $\begin{array}{l}-0.052 \\
{[0.783]}\end{array}$ & $\begin{array}{l}-0.047 \\
{[0.806]}\end{array}$ & $\begin{array}{l}-0.021 \\
{[0.911]}\end{array}$ & $\begin{array}{c}-0.02 \\
{[0.915]}\end{array}$ & $\begin{array}{l}-0.032 \\
{[0.866]}\end{array}$ & $\begin{array}{l}-0.039 \\
{[0.837]}\end{array}$ & $\begin{array}{l}-0.038 \\
{[0.839]}\end{array}$ & $\begin{array}{l}-0.045 \\
{[0.810]}\end{array}$ \\
\hline Competed & $\begin{array}{l}-0.021 \\
{[0.976]}\end{array}$ & $\begin{array}{c}0.004 \\
{[0.995]}\end{array}$ & $\begin{array}{c}0.208 \\
{[0.758]}\end{array}$ & $\begin{array}{c}0.243 \\
{[0.722]}\end{array}$ & $\begin{array}{c}0.092 \\
{[0.893]}\end{array}$ & $\begin{array}{c}0.082 \\
{[0.904]}\end{array}$ & $\begin{array}{c}0.101 \\
{[0.882]}\end{array}$ & $\begin{array}{c}0.099 \\
{[0.885]}\end{array}$ \\
\hline Tender & $\begin{array}{l}1.025 * * \\
{[0.043]}\end{array}$ & $\begin{array}{l}0.943^{*} \\
{[0.069]}\end{array}$ & $\begin{array}{l}0.964 * \\
{[0.059]}\end{array}$ & $\begin{array}{l}0.882 * \\
{[0.092]}\end{array}$ & $\begin{array}{l}1.021^{* *} \\
{[0.046]}\end{array}$ & $\begin{array}{l}1.025 * * \\
{[0.045]}\end{array}$ & $\begin{array}{l}1.031 * * \\
{[0.046]}\end{array}$ & $\begin{array}{l}1.023 * * \\
{[0.047]}\end{array}$ \\
\hline Friendly & $\begin{array}{l}-0.429 \\
{[0.426]}\end{array}$ & $\begin{array}{l}-0.367 \\
{[0.503]}\end{array}$ & $\begin{array}{l}-0.537 \\
{[0.323]}\end{array}$ & $\begin{array}{l}-0.465 \\
{[0.399]}\end{array}$ & $\begin{array}{c}-0.603 \\
{[0.265]}\end{array}$ & $\begin{array}{c}-0.539 \\
{[0.317]}\end{array}$ & $\begin{array}{c}-0.544 \\
{[0.319]}\end{array}$ & $\begin{array}{c}-0.495 \\
{[0.361]}\end{array}$ \\
\hline Cross-border & $\begin{array}{c}-0.323^{*} \\
{[0.097]}\end{array}$ & $\begin{array}{c}-0.28 \\
{[0.147]}\end{array}$ & $\begin{array}{c}-0.144 \\
{[0.478]}\end{array}$ & $\begin{array}{l}-0.099 \\
{[0.621]}\end{array}$ & $\begin{array}{l}-0.231 \\
{[0.238]}\end{array}$ & $\begin{array}{l}-0.271 \\
{[0.164]}\end{array}$ & $\begin{array}{l}-0.222 \\
{[0.253]}\end{array}$ & $\begin{array}{c}-0.259 \\
{[0.178]}\end{array}$ \\
\hline Cash only & $\begin{array}{l}-0.136 \\
{[0.367]}\end{array}$ & $\begin{array}{l}-0.123 \\
{[0.410]}\end{array}$ & $\begin{array}{l}-0.075 \\
{[0.611]}\end{array}$ & $\begin{array}{l}-0.066 \\
{[0.649]}\end{array}$ & $\begin{array}{l}-0.094 \\
{[0.521]}\end{array}$ & $\begin{array}{l}-0.117 \\
{[0.433]}\end{array}$ & $\begin{array}{l}-0.116 \\
{[0.438]}\end{array}$ & $\begin{array}{l}-0.135 \\
{[0.369]}\end{array}$ \\
\hline Stock only & $\begin{array}{c}-0.664 * * * \\
{[0.003]}\end{array}$ & $\begin{array}{c}-0.648 * * * * \\
{[0.004]}\end{array}$ & $\begin{array}{c}-0.601 * * * \\
{[0.007]}\end{array}$ & $\begin{array}{c}-0.581 * * * \\
{[0.009]}\end{array}$ & $\begin{array}{c}-0.624 * * * \\
{[0.005]}\end{array}$ & $\begin{array}{c}-0.641 * * * \\
{[0.004]}\end{array}$ & $\begin{array}{c}-0.648 * * * \\
{[0.003]}\end{array}$ & $\begin{array}{c}-0.662^{* * * *} \\
{[0.003]}\end{array}$ \\
\hline Public target & $\begin{array}{c}-3.347 * * * \\
{[0.000]}\end{array}$ & $\begin{array}{c}-3.307 * * * * \\
{[0.000]}\end{array}$ & $\begin{array}{c}-2.984 * * * \\
{[0.000]}\end{array}$ & $\begin{array}{c}-2.939 * * * \\
{[0.000]}\end{array}$ & $\begin{array}{c}-3.187 * * * \\
{[0.000]}\end{array}$ & $\begin{array}{c}-3.224 * * * \\
{[0.000]}\end{array}$ & $\begin{array}{c}-3.157 * * * \\
{[0.000]}\end{array}$ & $\begin{array}{c}-3.194 * * * \\
{[0.000]}\end{array}$ \\
\hline Private target & $\begin{array}{c}-0.406 * * * \\
{[0.003]}\end{array}$ & $\begin{array}{c}-0.381 * * * * \\
{[0.006]}\end{array}$ & $\begin{array}{c}-0.628 * * * \\
{[0.000]}\end{array}$ & $\begin{array}{c}-0.601 * * * \\
{[0.000]}\end{array}$ & $\begin{array}{c}-0.552 * * * \\
{[0.000]}\end{array}$ & $\begin{array}{c}-0.515^{* * *} * \\
{[0.000]}\end{array}$ & $\begin{array}{c}-0.543 * * * \\
{[0.000]}\end{array}$ & $\begin{array}{c}-0.503 \text { *** } \\
{[0.000]}\end{array}$ \\
\hline Home market capitalization & $\begin{array}{c}2.784 \\
{[0.902]}\end{array}$ & $\begin{array}{l}-1.285 \\
{[0.955]}\end{array}$ & $\begin{array}{c}1.865 \\
{[0.935]}\end{array}$ & $\begin{array}{l}-4.007 \\
{[0.862]}\end{array}$ & $\begin{array}{c}2.66 \\
{[0.898]}\end{array}$ & $\begin{array}{c}2.51 \\
{[0.905]}\end{array}$ & $\begin{array}{c}1.46 \\
{[0.946]}\end{array}$ & $\begin{array}{c}1.495 \\
{[0.945]}\end{array}$ \\
\hline Home turnover & $\begin{array}{c}0.12 \\
{[0.638]}\end{array}$ & $\begin{array}{c}0.129 \\
{[0.606]}\end{array}$ & $\begin{array}{c}0.253 \\
{[0.305]}\end{array}$ & $\begin{array}{c}0.254 \\
{[0.296]}\end{array}$ & $\begin{array}{c}0.322 \\
{[0.194]}\end{array}$ & $\begin{array}{c}0.281 \\
{[0.257]}\end{array}$ & $\begin{array}{c}0.224 \\
{[0.376]}\end{array}$ & $\begin{array}{c}0.189 \\
{[0.453]}\end{array}$ \\
\hline FDI & $\begin{array}{c}-1.248 \\
{[0.552]}\end{array}$ & $\begin{array}{l}-1.343 \\
{[0.530]}\end{array}$ & $\begin{array}{l}-1.262 \\
{[0.555]}\end{array}$ & $\begin{array}{l}-1.391 \\
{[0.526]}\end{array}$ & $\begin{array}{c}-1.103 \\
{[0.597]}\end{array}$ & $\begin{array}{c}-1.186 \\
{[0.579]}\end{array}$ & $\begin{array}{c}-1.356 \\
{[0.526]}\end{array}$ & $\begin{array}{c}-1.424 \\
{[0.515]}\end{array}$ \\
\hline Unemployment & $\begin{array}{c}-0.03 \\
{[0.498]}\end{array}$ & $\begin{array}{c}-0.03 \\
{[0.544]}\end{array}$ & $\begin{array}{l}-0.038 \\
{[0.410]}\end{array}$ & $\begin{array}{l}-0.041 \\
{[0.407]}\end{array}$ & $\begin{array}{l}-0.026 \\
{[0.561]}\end{array}$ & $\begin{array}{l}-0.025 \\
{[0.567]}\end{array}$ & $\begin{array}{l}-0.036 \\
{[0.420]}\end{array}$ & $\begin{array}{l}-0.036 \\
{[0.421]}\end{array}$ \\
\hline Trade imbalance & $\begin{array}{l}-2.158^{*} \\
{[0.091]}\end{array}$ & $\begin{array}{c}-2.508^{*} \\
{[0.066]}\end{array}$ & $\begin{array}{l}-1.846 \\
{[0.150]}\end{array}$ & $\begin{array}{c}-2.335^{*} \\
{[0.087]}\end{array}$ & $\begin{array}{c}-2.257^{*} \\
{[0.065]}\end{array}$ & $\begin{array}{c}-2.365^{*} \\
{[0.051]}\end{array}$ & $\begin{array}{c}-2.654^{* *} \\
{[0.030]}\end{array}$ & $\begin{array}{c}-2.800 * * \\
{[0.021]}\end{array}$ \\
\hline Constant & $\begin{array}{c}1.409 \\
{[0.454]}\end{array}$ & $\begin{array}{c}2.042 \\
{[0.389]}\end{array}$ & $\begin{array}{l}-2.653 \\
{[0.221]}\end{array}$ & $\begin{array}{l}-1.404 \\
{[0.585]}\end{array}$ & $\begin{array}{c}2.874 * * * * \\
{[0.000]}\end{array}$ & $\begin{array}{c}2.728 * * * \\
{[0.000]}\end{array}$ & $\begin{array}{c}2.819 * * * \\
{[0.000]}\end{array}$ & $\begin{array}{c}2.708 * * * \\
{[0.001]}\end{array}$ \\
\hline $\begin{array}{l}\text { Observations } \\
\text { Adjusted } \mathrm{R}^{2}\end{array}$ & $\begin{array}{l}17647 \\
2.90 \%\end{array}$ & $\begin{array}{l}17459 \\
2.90 \%\end{array}$ & $\begin{array}{l}17647 \\
3.30 \%\end{array}$ & $\begin{array}{l}17459 \\
3.30 \%\end{array}$ & $\begin{array}{l}17,647 \\
3.10 \%\end{array}$ & $\begin{array}{l}17,647 \\
3.00 \%\end{array}$ & $\begin{array}{l}17,647 \\
3.10 \%\end{array}$ & $\begin{array}{l}17,647 \\
3.00 \%\end{array}$ \\
\hline
\end{tabular}


Table 6: Takeover approval (deal completion) regressions

The table reports OLS regressions that examine the length of time to deal completion. The dependent variable is the number of days to deal completion, measured from the deal announcement date to the completion date. Detailed variable definitions are reported in appendix 1. The models include year dummies (untabulated). $P$-values calculated using heteroskedasticity-consistent standard errors and corrected for industry-level clustering (using 4-digit SIC industry codes) are reported in parentheses. Superscripts ***, **, and *, denote significance at $1 \%, 5 \%$, and $10 \%$, respectively.

\begin{tabular}{|c|c|c|c|c|c|c|}
\hline \multirow[t]{2}{*}{ Dependent Variable } & \multicolumn{6}{|c|}{ Days to completion } \\
\hline & [1] & [2] & [3] & [4] & [5] & [6] \\
\hline Ln(Assets) & $\begin{array}{c}0.604 \\
{[0.348]}\end{array}$ & $1.257 * *$ & & & & \\
\hline WB Gov. Index & $\begin{array}{c}-206.427 * * * \\
{[0.000]}\end{array}$ & & & & & \\
\hline Ln(Assets)* WB Gov. Index & $\begin{array}{c}4.711 * * * \\
{[0.000]}\end{array}$ & & & & & \\
\hline ICRG Political Index & & $\begin{array}{c}-282.221 * * * \\
{[0.000]}\end{array}$ & & & & \\
\hline Ln(Assets)* ICRG Political Index & & $\begin{array}{c}4.495 * * * \\
{[0.000]}\end{array}$ & & & & \\
\hline Size top $25 \%$ & & & $\begin{array}{c}20.977 * * * \\
{[0.000]}\end{array}$ & $\begin{array}{c}23.958 * * * \\
{[0.000]}\end{array}$ & & \\
\hline Size top $10 \%$ & & & & & $\begin{array}{c}36.043 * * * \\
{[0.000]}\end{array}$ & $\begin{array}{c}37.380 * * * \\
{[0.000]}\end{array}$ \\
\hline Weak WB Gov. x Size top $25 \%$ & & & $\begin{array}{c}0.287 \\
{[0.917]}\end{array}$ & & & \\
\hline Weak Political Gov. x Size top 25\% & & & & $\begin{array}{l}-4.859 \\
{[0.163]}\end{array}$ & & \\
\hline Weak WB Gov. x Size top $10 \%$ & & & & & $\begin{array}{c}-11.414 * * \\
{[0.037]}\end{array}$ & \\
\hline Weak Political Gov. x Size top $10 \%$ & & & & & & $\begin{array}{c}-14.377 * * * \\
{[0.009]}\end{array}$ \\
\hline Weak WB Gov. & & & $\begin{array}{c}12.319 * * * \\
{[0.000]}\end{array}$ & & $\begin{array}{c}13.180 * * * \\
{[0.000]}\end{array}$ & \\
\hline Weak Political Gov. & & & & $\begin{array}{c}18.747 * * * \\
{[0.000]}\end{array}$ & & $\begin{array}{c}19.013 * * * \\
{[0.000]}\end{array}$ \\
\hline Tobin's q & $\begin{array}{c}0.975 * * \\
{[0.024]}\end{array}$ & $\begin{array}{c}1.359 * * * \\
{[0.004]}\end{array}$ & $\begin{array}{c}0.727 \\
{[0.127]}\end{array}$ & $\begin{array}{c}1.045 * * \\
{[0.027]}\end{array}$ & $\begin{array}{c}0.756 \\
{[0.113]}\end{array}$ & $\begin{array}{c}1.063 * * \\
{[0.025]}\end{array}$ \\
\hline Relative size & $\begin{array}{c}33.679 * * * \\
{[0.000]}\end{array}$ & $\begin{array}{c}33.160^{* * * *} \\
{[0.000]}\end{array}$ & $\begin{array}{c}31.742 * * * \\
{[0.000]}\end{array}$ & $\begin{array}{c}31.909 * * * \\
{[0.000]}\end{array}$ & $\begin{array}{c}31.086 * * * * \\
{[0.000]}\end{array}$ & $\begin{array}{c}31.225 * * * \\
{[0.000]}\end{array}$ \\
\hline Return on assets & $\begin{array}{c}-8.506^{*} \\
{[0.065]}\end{array}$ & $\begin{array}{c}-7.059 \\
{[0.111]}\end{array}$ & $\begin{array}{c}1.436 \\
{[0.734]}\end{array}$ & $\begin{array}{c}0.26 \\
{[0.951]}\end{array}$ & $\begin{array}{c}2.37 \\
{[0.570]}\end{array}$ & $\begin{array}{c}1.216 \\
{[0.772]}\end{array}$ \\
\hline Leverage & $\begin{array}{c}-14.662 * \\
{[0.051]}\end{array}$ & $\begin{array}{l}-10.793 \\
{[0.152]}\end{array}$ & $\begin{array}{l}-5.582 \\
{[0.505]}\end{array}$ & $\begin{array}{c}-5.642 \\
{[0.477]}\end{array}$ & $\begin{array}{l}-1.035 \\
{[0.903]}\end{array}$ & $\begin{array}{c}-0.985 \\
{[0.904]}\end{array}$ \\
\hline Cash-holdings & $\begin{array}{l}-8.723^{*} \\
{[0.075]}\end{array}$ & $\begin{array}{c}-9.535^{*} \\
{[0.058]}\end{array}$ & $\begin{array}{c}-3.856 \\
{[0.434]}\end{array}$ & $\begin{array}{l}-4.353 \\
{[0.378]}\end{array}$ & $\begin{array}{c}-5.657 \\
{[0.258]}\end{array}$ & $\begin{array}{c}-6.064 \\
{[0.226]}\end{array}$ \\
\hline CAPEX & $\begin{array}{c}-7.16 \\
{[0.505]}\end{array}$ & $\begin{array}{l}-8.419 \\
{[0.442]}\end{array}$ & $\begin{array}{l}-7.982 \\
{[0.452]}\end{array}$ & $\begin{array}{l}-10.871 \\
{[0.336]}\end{array}$ & $\begin{array}{l}-7.004 \\
{[0.503]}\end{array}$ & $\begin{array}{l}-10.22 \\
{[0.356]}\end{array}$ \\
\hline Diversifying & $\begin{array}{c}-5.797 * * \\
{[0.025]}\end{array}$ & $\begin{array}{c}-6.252^{* *} \\
{[0.018]}\end{array}$ & $\begin{array}{c}-5.712 * * \\
{[0.033]}\end{array}$ & $\begin{array}{c}-6.159^{* *} \\
{[0.023]}\end{array}$ & $\begin{array}{c}-5.579^{* * *} \\
{[0.037]}\end{array}$ & $\begin{array}{c}-6.057 * * \\
{[0.025]}\end{array}$ \\
\hline Competed & $\begin{array}{c}39.355 * * * \\
{[0.000]}\end{array}$ & $\begin{array}{c}41.500 * * * \\
{[0.000]}\end{array}$ & $\begin{array}{c}41.307 * * * * \\
{[0.000]}\end{array}$ & $\begin{array}{c}41.265^{* * * *} \\
{[0.000]}\end{array}$ & $\begin{array}{c}40.846^{* * * * *} \\
{[0.000]}\end{array}$ & $\begin{array}{c}40.647 * * * \\
{[0.000]}\end{array}$ \\
\hline Tender & $\begin{array}{c}-31.320^{* * * *} \\
{[0.000]}\end{array}$ & $\begin{array}{c}-31.080^{* * * *} \\
{[0.000]}\end{array}$ & $\begin{array}{c}-34.657 * * * * \\
{[0.000]}\end{array}$ & $\begin{array}{c}-34.809^{* * * *} \\
{[0.000]}\end{array}$ & $\begin{array}{c}-34.966 * * * * \\
{[0.000]}\end{array}$ & $\begin{array}{c}-34.742^{* * * *} * \\
{[0.000]}\end{array}$ \\
\hline Friendly & $\begin{array}{c}-28.992 * * * \\
{[0.000]}\end{array}$ & $\begin{array}{c}-31.494 * * * \\
{[0.000]}\end{array}$ & $\begin{array}{c}-37.088 * * * * \\
{[0.000]}\end{array}$ & $\begin{array}{c}-35.818^{* * * *} \\
{[0.000]}\end{array}$ & $\begin{array}{c}-37.494 * * * * \\
{[0.000]}\end{array}$ & $\begin{array}{c}-36.188^{* * * *} \\
{[0.000]}\end{array}$ \\
\hline Cross-border & $\begin{array}{l}-2.411 \\
{[0.117]}\end{array}$ & $\begin{array}{c}-3.381 * * \\
{[0.033]}\end{array}$ & $\begin{array}{c}-4.702 * * * \\
{[0.003]}\end{array}$ & $\begin{array}{c}-4.501 * * * * \\
{[0.005]}\end{array}$ & $\begin{array}{c}-4.284 * * * * \\
{[0.004]}\end{array}$ & $\begin{array}{c}-4.026 * * * \\
{[0.009]}\end{array}$ \\
\hline Cash only & $\begin{array}{c}-4.602 * * * \\
{[0.001]}\end{array}$ & $\begin{array}{c}-4.415 * * * * \\
{[0.002]}\end{array}$ & $\begin{array}{c}-4.033^{* * * *} \\
{[0.006]}\end{array}$ & $\begin{array}{c}-4.020^{* * * *} \\
{[0.007]}\end{array}$ & $\begin{array}{c}-3.559^{* *} \\
{[0.012]}\end{array}$ & $\begin{array}{c}-3.557^{* *} \\
{[0.012]}\end{array}$ \\
\hline Stock only & $\begin{array}{c}22.895 * * * \\
{[0.000]}\end{array}$ & $\begin{array}{c}23.501 * * * \\
{[0.000]}\end{array}$ & $\begin{array}{c}26.587 * * * \\
{[0.000]}\end{array}$ & $\begin{array}{c}26.024 * * * \\
{[0.000]}\end{array}$ & $\begin{array}{c}26.923 * * * \\
{[0.000]}\end{array}$ & $\begin{array}{c}26.321 * * * \\
{[0.000]}\end{array}$ \\
\hline Public target & $\begin{array}{c}52.371 * * * \\
{[0.000]}\end{array}$ & $\begin{array}{c}51.926 * * * \\
{[0.000]}\end{array}$ & $\begin{array}{c}50.937 * * * \\
{[0.000]}\end{array}$ & $\begin{array}{c}51.296 * * * \\
{[0.000]}\end{array}$ & $\begin{array}{c}51.036^{* * * *} \\
{[0.000]}\end{array}$ & $\begin{array}{c}51.300 * * * \\
{[0.000]}\end{array}$ \\
\hline Private target & $\begin{array}{c}-19.298 * * * \\
{[0.000]}\end{array}$ & $\begin{array}{c}-19.350 * * * \\
{[0.000]}\end{array}$ & $\begin{array}{c}-21.276^{* * * *} \\
{[0.000]}\end{array}$ & $\begin{array}{c}-20.774 * * * * \\
{[0.000]}\end{array}$ & $\begin{array}{c}-21.777 * * * * \\
{[0.000]}\end{array}$ & $\begin{array}{c}-21.228 * * * \\
{[0.000]}\end{array}$ \\
\hline Home market capitalization & $\begin{array}{c}1,000.532 * * * \\
{[0.000]}\end{array}$ & $\begin{array}{c}1,154.772 * * * * \\
{[0.000]}\end{array}$ & $\begin{array}{c}371.691 * \\
{[0.099]}\end{array}$ & $\begin{array}{c}631.871 * * * * \\
{[0.006]}\end{array}$ & $\begin{array}{c}346.691 \\
{[0.120]}\end{array}$ & $\begin{array}{c}617.369 * * * * \\
{[0.006]}\end{array}$ \\
\hline Home turnover & $\begin{array}{c}-9.869 * * * \\
{[0.000]}\end{array}$ & $\begin{array}{c}-16.478 * * * * \\
{[0.000]}\end{array}$ & $\begin{array}{c}-13.032 * * * * \\
{[0.000]}\end{array}$ & $\begin{array}{c}-15.216 * * * \\
{[0.000]}\end{array}$ & $\begin{array}{c}-12.888 * * * * \\
{[0.000]}\end{array}$ & $\begin{array}{c}-14.974 * * * \\
{[0.000]}\end{array}$ \\
\hline FDI & $\begin{array}{r}-13.463 \\
{[0.243]}\end{array}$ & $\begin{array}{c}-28.957 * * \\
{[0.022]}\end{array}$ & $\begin{array}{c}-38.708 * * * \\
{[0.004]}\end{array}$ & $\begin{array}{c}-48.655^{* * * *} \\
{[0.002]}\end{array}$ & $\begin{array}{c}-37.900 * * * \\
{[0.003]}\end{array}$ & $\begin{array}{c}-47.633 * * * \\
{[0.001]}\end{array}$ \\
\hline Unemployment & $\begin{array}{c}-2.983 * * * \\
{[0.000]}\end{array}$ & $\begin{array}{c}-3.918 * * * \\
{[0.000]}\end{array}$ & $\begin{array}{c}-2.757 * * * \\
{[0.000]}\end{array}$ & $\begin{array}{c}-3.126 * * * \\
{[0.000]}\end{array}$ & $\begin{array}{c}-2.746 * * * \\
{[0.000]}\end{array}$ & $\begin{array}{c}-3.127 * * * \\
{[0.000]}\end{array}$ \\
\hline Trade imbalance & $\begin{array}{c}-64.806^{* * * *} \\
{[0.000]}\end{array}$ & $\begin{array}{c}-70.996^{* * * *} \\
{[0.000]}\end{array}$ & $\begin{array}{c}-98.346 * * * * \\
{[0.000]}\end{array}$ & $\begin{array}{c}-106.042^{* * * *} \\
{[0.000]}\end{array}$ & $\begin{array}{c}-90.903^{* * * *} \\
{[0.000]}\end{array}$ & $\begin{array}{c}-100.325^{* * * *} \\
{[0.000]}\end{array}$ \\
\hline Constant & $\begin{array}{c}217.304 * * * * \\
{[0.000]}\end{array}$ & $\begin{array}{c}277.701^{* * * *} \\
{[0.000]}\end{array}$ & $\begin{array}{c}102.791 * * * * \\
{[0.000]}\end{array}$ & $\begin{array}{c}101.682 * * * \\
{[0.000]}\end{array}$ & $\begin{array}{c}103.717^{* * * *} \\
{[0.000]}\end{array}$ & $\begin{array}{c}102.763 * * * * \\
{[0.000]}\end{array}$ \\
\hline Observations & 17,646 & 17,458 & 17,646 & 17,646 & 17,646 & 17,646 \\
\hline Adjusted $\mathrm{R}^{2}$ & $25.30 \%$ & $24.90 \%$ & $23.10 \%$ & $23.60 \%$ & $23.10 \%$ & $23.70 \%$ \\
\hline
\end{tabular}


Table 7: Deal mood regressions

The table reports logit regressions that examine the mood of the takeover. The dependent variable is equal to 1 if the deal is friendly, and 0 otherwise. Detailed variable definitions are reported in appendix 1 . The models include year dummies (untabulated). $P$-values calculated using heteroskedasticityconsistent standard errors and corrected for industry-level clustering (using 4-digit SIC industry codes) are reported in parentheses. Superscripts ${ }^{* * *},{ }^{* *}$, and $*$, denote significance at $1 \%, 5 \%$, and $10 \%$.

\begin{tabular}{|c|c|c|c|c|c|c|}
\hline \multirow[t]{2}{*}{ Dependent Variable } & \multicolumn{6}{|c|}{ Friendly Deal Indicator } \\
\hline & [1] & [2] & [3] & [4] & [5] & [6] \\
\hline Ln(Assets) & $\begin{array}{c}0.094 * * \\
{[0.023]}\end{array}$ & $\begin{array}{l}0.076^{*} \\
{[0.066]}\end{array}$ & & & & \\
\hline WB Gov. Index & $\begin{array}{c}5.871 * * * \\
{[0.000]}\end{array}$ & & & & & \\
\hline Ln(Assets)* WB Gov. Index & $\begin{array}{c}-0.156 * * * \\
{[0.001]}\end{array}$ & & & & & \\
\hline ICRG Political Index & & $\begin{array}{c}8.868 * * * \\
{[0.000]}\end{array}$ & & & & \\
\hline Ln(Assets)* ICRG Political Index & & $\begin{array}{c}-0.127 * * * \\
{[0.009]}\end{array}$ & & & & \\
\hline Size top $25 \%$ & & & $\begin{array}{c}-1.575 * * * * \\
{[0.000]}\end{array}$ & $\begin{array}{c}-1.446 * * * \\
{[0.000]}\end{array}$ & & \\
\hline Size top $10 \%$ & & & & & $\begin{array}{c}-1.001 * * * \\
{[0.001]}\end{array}$ & $\begin{array}{c}-1.203^{* * * *} \\
{[0.000]}\end{array}$ \\
\hline Weak WB Gov. x Size top $25 \%$ & & & $\begin{array}{c}1.406 * * * \\
{[0.000]}\end{array}$ & & & \\
\hline Weak Political Gov. x Size top 25\% & & & & $\begin{array}{c}1.338 * * * \\
{[0.000]}\end{array}$ & & \\
\hline Weak WB Gov. x Size top $10 \%$ & & & & & $\begin{array}{l}0.618^{*} \\
{[0.097]}\end{array}$ & \\
\hline Weak Political Gov. x Size top $10 \%$ & & & & & & $\begin{array}{c}1.046^{* * * *} \\
{[0.004]}\end{array}$ \\
\hline Weak WB Gov. & & & $\begin{array}{c}-1.348 * * * \\
{[0.000]}\end{array}$ & & $\begin{array}{c}-0.894 * * * \\
{[0.000]}\end{array}$ & \\
\hline Weak Political Gov. & & & & $\begin{array}{c}-1.102 * * * \\
{[0.000]}\end{array}$ & & $\begin{array}{c}-0.793 * * * * \\
{[0.000]}\end{array}$ \\
\hline Tobin's q & $\begin{array}{c}0.049 \\
{[0.277]}\end{array}$ & $\begin{array}{c}0.033 \\
{[0.467]}\end{array}$ & $\begin{array}{c}0.027 \\
{[0.556]}\end{array}$ & $\begin{array}{c}0.028 \\
{[0.544]}\end{array}$ & $\begin{array}{c}0.029 \\
{[0.523]}\end{array}$ & $\begin{array}{c}0.029 \\
{[0.516]}\end{array}$ \\
\hline Relative size & $\begin{array}{c}-0.373 * * * \\
{[0.001]}\end{array}$ & $\begin{array}{c}-0.342 * * * \\
{[0.002]}\end{array}$ & $\begin{array}{c}-0.348 * * * \\
{[0.001]}\end{array}$ & $\begin{array}{c}-0.354 * * * \\
{[0.001]}\end{array}$ & $\begin{array}{c}-0.331 * * * \\
{[0.001]}\end{array}$ & $\begin{array}{c}-0.331 * * * \\
{[0.001]}\end{array}$ \\
\hline Return on assets & $\begin{array}{c}0.371 \\
{[0.365]}\end{array}$ & $\begin{array}{c}0.239 \\
{[0.559]}\end{array}$ & $\begin{array}{c}0.194 \\
{[0.628]}\end{array}$ & $\begin{array}{c}0.208 \\
{[0.602]}\end{array}$ & $\begin{array}{c}0.058 \\
{[0.882]}\end{array}$ & $\begin{array}{c}0.09 \\
{[0.819]}\end{array}$ \\
\hline Leverage & $\begin{array}{c}0.166 \\
{[0.706]}\end{array}$ & $\begin{array}{c}0.052 \\
{[0.904]}\end{array}$ & $\begin{array}{c}0.051 \\
{[0.909]}\end{array}$ & $\begin{array}{c}0.114 \\
{[0.799]}\end{array}$ & $\begin{array}{c}-0.113 \\
{[0.797]}\end{array}$ & $\begin{array}{c}-0.083 \\
{[0.850]}\end{array}$ \\
\hline Cash-holdings & $\begin{array}{l}-0.790^{*} \\
{[0.065]}\end{array}$ & $\begin{array}{l}-0.728^{*} \\
{[0.092]}\end{array}$ & $\begin{array}{c}-0.932 * * \\
{[0.038]}\end{array}$ & $\begin{array}{l}-0.865^{*} \\
{[0.051]}\end{array}$ & $\begin{array}{l}-0.735^{*} \\
{[0.097]}\end{array}$ & $\begin{array}{c}-0.695 \\
{[0.113]}\end{array}$ \\
\hline CAPEX & $\begin{array}{c}1.501 * \\
{[0.074]}\end{array}$ & $\begin{array}{l}1.392^{*} \\
{[0.083]}\end{array}$ & $\begin{array}{c}0.986 \\
{[0.229]}\end{array}$ & $\begin{array}{c}1.296 \\
{[0.109]}\end{array}$ & $\begin{array}{c}1.117 \\
{[0.170]}\end{array}$ & $\begin{array}{l}1.368^{*} \\
{[0.092]}\end{array}$ \\
\hline Diversifying & $\begin{array}{c}-0.049 \\
{[0.707]}\end{array}$ & $\begin{array}{c}-0.017 \\
{[0.891]}\end{array}$ & $\begin{array}{c}-0.035 \\
{[0.780]}\end{array}$ & $\begin{array}{c}-0.02 \\
{[0.874]}\end{array}$ & $\begin{array}{c}-0.058 \\
{[0.648]}\end{array}$ & $\begin{array}{c}-0.043 \\
{[0.738]}\end{array}$ \\
\hline Tender offer & $\begin{array}{c}-1.606^{* * *} * \\
{[0.000]}\end{array}$ & $\begin{array}{c}-1.574 * * * \\
{[0.000]}\end{array}$ & $\begin{array}{c}-1.562 * * * \\
{[0.000]}\end{array}$ & $\begin{array}{c}-1.528 * * * \\
{[0.000]}\end{array}$ & $\begin{array}{c}-1.561 * * * \\
{[0.000]}\end{array}$ & $\begin{array}{c}-1.540 * * * \\
{[0.000]}\end{array}$ \\
\hline Cross-border & $\begin{array}{c}0.033 \\
{[0.826]}\end{array}$ & $\begin{array}{c}0.025 \\
{[0.862]}\end{array}$ & $\begin{array}{c}0.107 \\
{[0.466]}\end{array}$ & $\begin{array}{c}0.128 \\
{[0.390]}\end{array}$ & $\begin{array}{c}0.078 \\
{[0.597]}\end{array}$ & $\begin{array}{c}0.092 \\
{[0.543]}\end{array}$ \\
\hline Cash only & $\begin{array}{c}-0.118 \\
{[0.460]}\end{array}$ & $\begin{array}{c}-0.134 \\
{[0.400]}\end{array}$ & $\begin{array}{c}-0.08 \\
{[0.598]}\end{array}$ & $\begin{array}{c}-0.11 \\
{[0.479]}\end{array}$ & $\begin{array}{c}-0.099 \\
{[0.518]}\end{array}$ & $\begin{array}{c}-0.126 \\
{[0.420]}\end{array}$ \\
\hline Stock only & $\begin{array}{c}0.165 \\
{[0.454]}\end{array}$ & $\begin{array}{c}0.166 \\
{[0.457]}\end{array}$ & $\begin{array}{c}0.146 \\
{[0.516]}\end{array}$ & $\begin{array}{c}0.142 \\
{[0.535]}\end{array}$ & $\begin{array}{c}0.152 \\
{[0.495]}\end{array}$ & $\begin{array}{c}0.137 \\
{[0.545]}\end{array}$ \\
\hline Public target & $\begin{array}{c}-1.009 * * * \\
{[0.000]}\end{array}$ & $\begin{array}{c}-1.049 * * * \\
{[0.000]}\end{array}$ & $\begin{array}{c}-0.957 * * * \\
{[0.000]}\end{array}$ & $\begin{array}{c}-0.927 * * * \\
{[0.000]}\end{array}$ & $\begin{array}{c}-1.005 * * * \\
{[0.000]}\end{array}$ & $\begin{array}{c}-0.967 * * * * \\
{[0.000]}\end{array}$ \\
\hline Private target & $\begin{array}{c}-0.804 * * * \\
{[0.000]}\end{array}$ & $\begin{array}{c}-0.777 * * * \\
{[0.000]}\end{array}$ & $\begin{array}{c}-0.740 * * * \\
{[0.000]}\end{array}$ & $\begin{array}{c}-0.752 * * * \\
{[0.000]}\end{array}$ & $\begin{array}{c}-0.701 * * * \\
{[0.000]}\end{array}$ & $\begin{array}{c}-0.710 * * * \\
{[0.000]}\end{array}$ \\
\hline Home market capitalization & $\begin{array}{c}-45.749 * * * \\
{[0.000]}\end{array}$ & $\begin{array}{c}-38.277 * * * \\
{[0.000]}\end{array}$ & $\begin{array}{c}-24.937 * * * \\
{[0.005]}\end{array}$ & $\begin{array}{c}-26.742 * * * \\
{[0.003]}\end{array}$ & $\begin{array}{c}-25.927 * * * \\
{[0.004]}\end{array}$ & $\begin{array}{c}-27.109 * * * \\
{[0.003]}\end{array}$ \\
\hline Home turnover & $\begin{array}{c}0.228 \\
{[0.279]}\end{array}$ & $\begin{array}{c}0.384^{*} \\
{[0.069]}\end{array}$ & $\begin{array}{c}0.638 * * * \\
{[0.004]}\end{array}$ & $\begin{array}{c}0.619 * * * \\
{[0.004]}\end{array}$ & $\begin{array}{c}0.592 * * * \\
{[0.009]}\end{array}$ & $\begin{array}{c}0.599 * * * \\
{[0.006]}\end{array}$ \\
\hline FDI & $\begin{array}{c}-0.954 * * \\
{[0.028]}\end{array}$ & $\begin{array}{c}-0.938 * * \\
{[0.031]}\end{array}$ & $\begin{array}{c}-0.621 \\
{[0.133]}\end{array}$ & $\begin{array}{c}-0.6 \\
{[0.140]}\end{array}$ & $\begin{array}{c}-0.746 \\
{[0.130]}\end{array}$ & $\begin{array}{c}-0.73 \\
{[0.154]}\end{array}$ \\
\hline Unemployment & $\begin{array}{c}0.145 * * * \\
{[0.003]}\end{array}$ & $\begin{array}{c}0.187 * * * \\
{[0.000]}\end{array}$ & $\begin{array}{c}0.165 * * * \\
{[0.002]}\end{array}$ & $\begin{array}{c}0.174 * * * \\
{[0.003]}\end{array}$ & $\begin{array}{c}0.167 * * * \\
{[0.003]}\end{array}$ & $\begin{array}{c}0.171 * * * \\
{[0.003]}\end{array}$ \\
\hline Trade imbalance & $\begin{array}{c}5.317 * * * \\
{[0.000]}\end{array}$ & $\begin{array}{c}6.168 * * * \\
{[0.000]}\end{array}$ & $\begin{array}{c}6.164 * * * \\
{[0.000]}\end{array}$ & $\begin{array}{c}5.893 * * * \\
{[0.000]}\end{array}$ & $\begin{array}{c}6.354 * * * \\
{[0.000]}\end{array}$ & $\begin{array}{c}5.954 * * * \\
{[0.000]}\end{array}$ \\
\hline Constant & $\begin{array}{c}0.772 \\
{[0.467]}\end{array}$ & $\begin{array}{c}-2.123 \\
{[0.104]}\end{array}$ & $\begin{array}{c}6.230 * * * \\
{[0.000]}\end{array}$ & $\begin{array}{c}5.870 * * * \\
{[0.000]}\end{array}$ & $\begin{array}{c}5.807 * * * \\
{[0.000]}\end{array}$ & $\begin{array}{c}5.588 * * * \\
{[0.000]}\end{array}$ \\
\hline Observations & 17,647 & 17,459 & 17,647 & 17,647 & 17,647 & 17,647 \\
\hline Pseudo $\mathrm{R}^{2}$ & $18.27 \%$ & $17.69 \%$ & $18.40 \%$ & $17.99 \%$ & $17.28 \%$ & $17.15 \%$ \\
\hline
\end{tabular}




\section{Table 8: Takeover premium regressions}

The table reports OLS regressions that examine the determinants of takeover premiums. The dependent variable is the target's takeover premium, calculated as [Transaction value/Target Market Value $(\mathrm{t})-1$ ] where we calculate the target's market value one week or four weeks before the acquisition (as denoted in the column headers). The key independent variables are Ln(Assets), the Governance Variables, and the interaction term 'Ln(Assets) x Governance.' The governance variables are the World Bank (WB) governance variables (columns 1 and 4), the ICRG composite index (columns 2 and 5), and the ICRG political index (columns 3 and 6). For all governance variables, a higher value indicates better governance. Detailed variable definitions are reported in appendix 1 . The models include year dummies (untabulated). $P$-values calculated using heteroskedasticity-consistent standard errors and corrected for industry-level clustering (using 4-digit SIC industry codes) are reported in parentheses. Superscripts ${ }^{* * *},{ }^{* *}$, and ${ }^{*}$, denote significance at $1 \%$, 5\%, and $10 \%$, respectively.

\begin{tabular}{|c|c|c|c|c|c|c|}
\hline \multirow[t]{2}{*}{ Dependent Variable } & \multicolumn{3}{|c|}{ Premium (1 Week) } & \multicolumn{3}{|c|}{ Premium (4 Weeks) } \\
\hline & [1] & [2] & [3] & [4] & [5] & [6] \\
\hline \multirow[t]{2}{*}{ Ln(Assets) } & -0.356 & -0.091 & -0.219 & -1.305 & $\begin{array}{l}-1.008 \\
\end{array}$ & -1.187 \\
\hline & {$[0.747]$} & {$[0.931]$} & {$[0.843]$} & {$[0.246]$} & {$[0.352]$} & {$[0.285]$} \\
\hline \multirow[t]{2}{*}{ WB Gov. Index } & 9.511 & & & -5.907 & & \\
\hline & [0.627] & & & {$[0.765]$} & & \\
\hline \multirow[t]{2}{*}{ Ln(Assets)* WB Gov. Index } & $-1.481 * *$ & & & $-1.405 * *$ & & \\
\hline & [0.018] & & & [0.041] & & \\
\hline \multirow[t]{2}{*}{ ICRG Composite Index } & & 10.333 & & & -27.342 & \\
\hline & & {$[0.824]$} & & & {$[0.575]$} & \\
\hline \multirow[t]{2}{*}{ Ln(Assets)* ICRG Composite Index } & & $-1.547 * *$ & & & $-1.376^{*}$ & \\
\hline & & [0.024] & & & {$[0.070]$} & \\
\hline \multirow[t]{2}{*}{ ICRG Political Index } & & & 8.319 & & & -12.278 \\
\hline & & & {$[0.789]$} & & & {$[0.702]$} \\
\hline \multirow[t]{2}{*}{ Ln(Assets)* ICRG Political Index } & & & $-1.488 * *$ & & & $-1.309^{*}$ \\
\hline & & & {$[0.024]$} & & & {$[0.076]$} \\
\hline \multirow[t]{2}{*}{ Tobin's q } & 0.283 & 0.258 & 0.266 & $1.348^{* * *}$ & $1.346^{* * *}$ & $1.373 * *$ \\
\hline & {$[0.526]$} & {$[0.569]$} & {$[0.559]$} & {$[0.017]$} & {$[0.018]$} & {$[0.015]$} \\
\hline \multirow[t]{2}{*}{ Relative size } & $-4.089 * *$ & $-4.185 * *$ & $-4.189 * *$ & -4.141 & $-4.262 *$ & -4.17 \\
\hline & {$[0.040]$} & {$[0.035]$} & [0.037] & {$[0.102]$} & [0.091] & {$[0.101]$} \\
\hline \multirow{2}{*}{ Return on assets } & -10.499 & -11.045 & -10.987 & -2.097 & -2.595 & -2.554 \\
\hline & {$[0.324]$} & {$[0.306]$} & {$[0.309]$} & {$[0.839]$} & {$[0.803]$} & {$[0.807]$} \\
\hline \multirow[t]{2}{*}{ Leverage } & 3.926 & 4.899 & 4.895 & 6.982 & 7.569 & 7.478 \\
\hline & {$[0.594]$} & {$[0.515]$} & {$[0.514]$} & {$[0.399]$} & {$[0.369]$} & {$[0.374]$} \\
\hline \multirow[t]{2}{*}{ Cash-holdings } & $16.098 * *$ & $15.935 * *$ & $15.855 * *$ & $13.272^{*}$ & $13.133^{*}$ & $12.985^{*}$ \\
\hline & [0.019] & {$[0.026]$} & [0.026] & {$[0.075]$} & [0.084] & {$[0.088]$} \\
\hline \multirow[t]{2}{*}{ CAPEX } & -14.563 & -14.727 & -14.582 & $-34.163 * *$ & $-33.601 * *$ & $-33.608 * *$ \\
\hline & {$[0.381]$} & {$[0.383]$} & {$[0.384]$} & {$[0.026]$} & {$[0.030]$} & {$[0.029]$} \\
\hline \multirow[t]{2}{*}{ Diversifying } & 1.32 & 1.303 & 1.31 & 0.509 & 0.329 & 0.353 \\
\hline & [0.519] & {$[0.536]$} & [0.533] & {$[0.833]$} & [0.893] & [0.885] \\
\hline \multirow[t]{2}{*}{ Competed } & $16.715 * * *$ & 17.212 *** & $17.255^{* * *}$ & $18.328 * * *$ & $18.748 * * *$ & $18.844 * * *$ \\
\hline & {$[0.000]$} & [0.000] & [0.000] & [0.000] & [0.000] & {$[0.000]$} \\
\hline Tender & 2.059 & 2.211 & 2.241 & 2.093 & 2.2 & 2.311 \\
\hline & {$[0.260]$} & {$[0.246]$} & {$[0.243]$} & {$[0.310]$} & {$[0.297]$} & {$[0.276]$} \\
\hline Friendly & $-8.942 * *$ & $-8.107 * *$ & $-8.204 * *$ & -3.219 & -2.301 & -2.423 \\
\hline & [0.023] & {$[0.040]$} & [0.038] & {$[0.431]$} & {$[0.574]$} & {$[0.556]$} \\
\hline Cross-border & $6.357 * * *$ & $6.539 * * *$ & $6.544 * * *$ & $8.508 * * *$ & $8.285^{* * *}$ & $8.398 * * *$ \\
\hline & {$[0.008]$} & {$[0.006]$} & {$[0.007]$} & {$[0.001]$} & {$[0.001]$} & {$[0.001]$} \\
\hline Cash only & 8.336 *** & $8.267 * * *$ & $8.243 * * *$ & $9.658 * * *$ & $9.610 * * *$ & $9.594 * * *$ \\
\hline & [0.000] & [0.001] & [0.001] & {$[0.000]$} & {$[0.000]$} & {$[0.000]$} \\
\hline Stock only & -1.799 & -1.599 & -1.642 & 0.832 & 0.95 & 0.899 \\
\hline & {$[0.466]$} & {$[0.525]$} & {$[0.513]$} & [0.753] & [0.721] & [0.735] \\
\hline Home market capitalization & 466.193 & 451.195 & 459.146 & $587.335^{*}$ & $611.757 *$ & $594.154 *$ \\
\hline & {$[0.142]$} & {$[0.177]$} & {$[0.163]$} & {$[0.085]$} & [0.092] & [0.090] \\
\hline Home turnover & 0.233 & -0.193 & -0.313 & 4.57 & 4.366 & 3.859 \\
\hline & [0.943] & {$[0.955]$} & [0.928] & [0.249] & {$[0.298]$} & {$[0.358]$} \\
\hline FDI & 8.462 & 8.563 & 8.484 & 3.216 & 3.514 & 3.363 \\
\hline & {$[0.652]$} & {$[0.648]$} & {$[0.649]$} & {$[0.853]$} & [0.841] & [0.846] \\
\hline Unemployment & -0.37 & -0.354 & -0.4 & -0.661 & -0.729 & -0.713 \\
\hline & [0.414] & {$[0.505]$} & [0.417] & {$[0.125]$} & [0.161] & [0.146] \\
\hline Trade imbalance & 19.07 & 19.668 & 21.264 & -1.232 & -10.115 & 1.426 \\
\hline & {$[0.204]$} & {$[0.362]$} & [0.167] & [0.944] & {$[0.686]$} & {$[0.937]$} \\
\hline Constant & $55.156^{*}$ & 49.354 & 53.254 & $81.970 * * *$ & $92.112 * *$ & $83.014 * *$ \\
\hline & {$[0.060]$} & {$[0.250]$} & [0.154] & [0.006] & {$[0.040]$} & {$[0.035]$} \\
\hline Observations & 1,889 & 1,865 & 1,865 & 1,895 & 1,871 & 1,871 \\
\hline Adjusted $\mathrm{R}^{2}$ & $9.40 \%$ & $9.40 \%$ & $9.40 \%$ & $10.10 \%$ & $10.00 \%$ & $10.00 \%$ \\
\hline
\end{tabular}


Table 9: Domestic and diversifying deals (CARs)

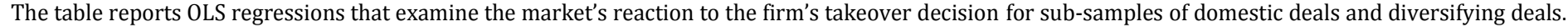

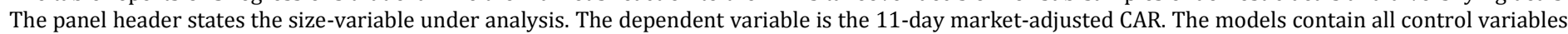

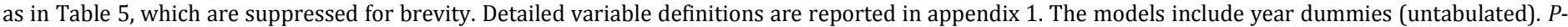

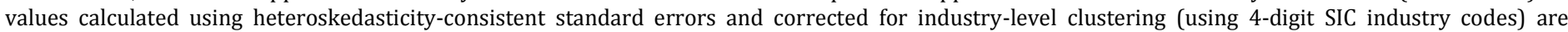
reported in parentheses. Superscripts $* * *, * *$, and *, denote significance at $1 \%, 5 \%$, and $10 \%$, respectively

Sample

Panel A: Continuous size variable

Ln(Assets)

WB Gov. Index

[1] [2]

Ln(Assets)* WB Gov. Index

[0.007]

$4.894 * * *$

[0.005]

$-0.419 * * *$

[0.000]

ICRG Political Index

Ln(Assets)* ICRG Political Index

3.16

[0.221]

$-0.423 * * *$

Controls

Observations

Adjusted $\mathrm{R}^{2}$

Panel B: Size top $10 \%$

Size top $10 \%$

Bad WB Gov.

Bad WB Gov. x Size top $10 \%$

Yes

13,085

$3.90 \%$

$-1.433 * * *$

[0.000]

$-0.38$

[0.152]

$0.921 * *$

[0.013]

Bad Political Gov.

Bad Political Gov. x Size top $10 \%$

Controls

Observations

R-squared

Panel C: Size top 25\%

Size top $25 \%$

Bad WB Gov.

Bad WB Gov. x Size top 25\%

Bad Political Gov.

Bad Political Gov. x Size top 25\%

Controls

Observations

R-squared
0.119

[0.575]

$0.642 *$

[0.072]

Yes

13,085

$3.60 \%$

$-1.490 * * *$

[0.000]

$-0.467 *$

[0.086]

$0.856^{* * * *}$

[0.004]

0.037

[0.869]

$0.686 * * *$

[0.005]

Yes

13,085

$3.80 \%$
Yes

13,085

$3.90 \%$
Diversifying

$290 * * *$

$[0.003] \quad[0.001]$

$5.353 * * *$

[0.004]

$-0.406 * * *$

[0.000]

$5.387 * *$

[0.027]

$-0.429 * * *$

[0.000]

Yes

$\begin{array}{ll}11,853 & 11,727 \\ 3.10 \% & 3.10 \%\end{array}$

$\begin{array}{ll}11,853 & 11,727 \\ 3.10 \% & 3.10 \%\end{array}$

$-1.400 * * * \quad-1.323 * * *$

[0.001] [0.001]

$-0.352$

[0.134]

0.678

[0.145]

0.023

[0.904]

0.609

[0.177]

Yes

11,853

$2.80 \%$

$\begin{array}{ll}11,853 & 11,853 \\ 2.80 \% & 2.80 \%\end{array}$

$-1.295^{* * *} \quad-1.236 * *$

[0.000] [0.000]

$-0.449 *$

[0.085]

0.677 **

[0.047]

$-0.059$

[0.783]

$0.611 * *$

[0.040]

Yes

Yes

11,853

$2.90 \%$ 


\section{Table 10: Examining the importance of connections}

The table reports OLS regressions that examine the importance of corporate size in countries where political connections are particularly important. The dependent variable is the 11-day market-adjusted CAR. The key independent variables are Ln(Assets). Detailed variable definitions are reported in appendix 1. The models include year dummies (untabulated). $P$-values calculated using heteroskedasticity-consistent standard errors and corrected for industry-level clustering (using 4-digit SIC industry codes) are reported in parentheses. Superscripts ***, **, and $*$, denote significance at $1 \%, 5 \%$, and $10 \%$, respectively.

\begin{tabular}{|c|c|c|c|}
\hline & [1] & [2] & [3] \\
\hline \multirow[t]{2}{*}{ Ln(Assets) } & 0.035 & -0.032 & -0.026 \\
\hline & {$[0.622]$} & {$[0.687]$} & {$[0.762]$} \\
\hline \multirow[t]{2}{*}{$\%$ Firms with MP/HOS or relative thereof } & $-1.575^{* * *}$ & & \\
\hline & [0.002] & & \\
\hline \multirow[t]{2}{*}{ Ln(Assets)* \% Firms with MP/HOS or relative thereof } & $0.080 * * *$ & & \\
\hline & {$[0.002]$} & & \\
\hline$\%$ Firms with MP/HOS & & $\begin{array}{c}-3.352 * * * \\
{[0.001]}\end{array}$ & \\
\hline \multirow[t]{2}{*}{ Ln(Assets)* \% Firms with MP/HOS } & & $0.167 * * *$ & \\
\hline & & [0.002] & \\
\hline$\%$ Top 50 Firms with MP/HOS or relative thereof & & & $\begin{array}{c}-0.961 * * * \\
{[0.000]}\end{array}$ \\
\hline \multirow[t]{2}{*}{$\operatorname{Ln}($ Assets)* \% Top 50 Firms with MP/HOS or relative thereof } & & & $0.049 * * *$ \\
\hline & & & {$[0.001]$} \\
\hline \multirow[t]{2}{*}{ Tobin's q } & $0.275^{* * *} *$ & $0.273^{* * *} *$ & $0.271 * * *$ \\
\hline & {$[0.000]$} & {$[0.000]$} & {$[0.000]$} \\
\hline \multirow[t]{2}{*}{ Relative size } & $1.452 * * *$ & $1.447 * * *$ & $1.441 * * *$ \\
\hline & {$[0.000]$} & {$[0.000]$} & {$[0.000]$} \\
\hline \multirow[t]{2}{*}{ Return on assets } & 0.311 & 0.328 & 0.261 \\
\hline & {$[0.646]$} & {$[0.630]$} & {$[0.696]$} \\
\hline \multirow[t]{2}{*}{ Leverage } & $-1.405 * *$ & $-1.442 * *$ & $-1.381 * *$ \\
\hline & {$[0.041]$} & {$[0.035]$} & {$[0.044]$} \\
\hline \multirow[t]{2}{*}{ Cash-holdings } & $-1.055^{* *}$ & $-1.044 * *$ & $-1.036^{* *}$ \\
\hline & {$[0.038]$} & [0.039] & {$[0.040]$} \\
\hline \multirow[t]{2}{*}{ CAPEX } & $-4.604 * * *$ & $-4.506^{* * *}$ & $-4.752 * * *$ \\
\hline & {$[0.000]$} & {$[0.000]$} & {$[0.000]$} \\
\hline \multirow[t]{2}{*}{ Diversifying } & 0.007 & 0.001 & 0.008 \\
\hline & {$[0.975]$} & [0.995] & [0.971] \\
\hline \multirow[t]{2}{*}{ Competed } & -0.074 & -0.079 & -0.089 \\
\hline & [0.918] & [0.912] & [0.901] \\
\hline \multirow[t]{2}{*}{ Tender } & $1.124 * *$ & $1.131^{* *}$ & $1.066^{*}$ \\
\hline & {$[0.049]$} & {$[0.047]$} & {$[0.065]$} \\
\hline \multirow[t]{2}{*}{ Friendly } & $-1.186^{* *}$ & $-1.157 * *$ & $-1.216^{* *}$ \\
\hline & {$[0.029]$} & {$[0.032]$} & {$[0.027]$} \\
\hline \multirow[t]{2}{*}{ Cross-border } & $-0.433^{*}$ & $-0.387^{*}$ & $-0.478 * *$ \\
\hline & {$[0.062]$} & {$[0.088]$} & [0.043] \\
\hline \multirow[t]{2}{*}{ Cash only } & -0.243 & -0.259 & -0.208 \\
\hline & {$[0.218]$} & {$[0.186]$} & {$[0.290]$} \\
\hline Stock only & $-0.715^{* * *}$ & $-0.726 * * *$ & $-0.689 * * *$ \\
\hline & [0.003] & [0.002] & [0.003] \\
\hline Public target & $-3.440 * * *$ & $-3.425 * * *$ & $-3.448 * * *$ \\
\hline & {$[0.000]$} & {$[0.000]$} & {$[0.000]$} \\
\hline Private target & $-0.432 * * *$ & $-0.428 * * *$ & $-0.441 * * *$ \\
\hline & {$[0.004]$} & [0.004] & [0.003] \\
\hline Home market capitalization & -1.656 & -7.681 & 2.464 \\
\hline & {$[0.940]$} & {$[0.731]$} & {$[0.910]$} \\
\hline Home turnover & -0.071 & -0.11 & 0.184 \\
\hline & {$[0.831]$} & {$[0.738]$} & {$[0.555]$} \\
\hline FDI & -0.629 & 0.416 & -1.058 \\
\hline & {$[0.771]$} & [0.847] & [0.634] \\
\hline Unemployment & -0.025 & -0.014 & -0.038 \\
\hline & {$[0.572]$} & {$[0.761]$} & {$[0.406]$} \\
\hline Trade imbalance & -1.537 & -2.053 & -0.352 \\
\hline & {$[0.251]$} & {$[0.121]$} & [0.789] \\
\hline Constant & 2.777 & $4.010^{* *}$ & $4.133^{* *}$ \\
\hline & {$[0.105]$} & {$[0.028]$} & [0.039] \\
\hline Observations & 14,340 & 14,340 & 14,340 \\
\hline Adjusted $\mathrm{R}^{2}$ & $3.40 \%$ & $3.40 \%$ & $3.50 \%$ \\
\hline
\end{tabular}


Table 11: Examining post-takeover operating performance

This table contains regressions that examine post-takeover improvements in operating performance. The dependent variable is an indicator that equals one if the acquirer's EBIT/Assets one year (Columns 1-2), two years (Columns 3-4), or three years (Columns 5-

6) after the acquisition exceeds its EBIT/Assets one year before the acquisitions. Detailed variable definitions are reported in appendix 1. The models include year dummies (untabulated). P-values calculated using heteroskedasticity-consistent standard errors and corrected for industry-level clustering (using 4-digit SIC industry codes) are reported in parentheses. Superscripts ***, **, and *, denote significance at $1 \%, 5 \%$, and $10 \%$, respectively.

\begin{tabular}{|c|c|c|c|c|c|c|}
\hline \multirow[t]{2}{*}{ Dependent Variable } & \multicolumn{2}{|c|}{ One Year Increase } & \multicolumn{2}{|c|}{ Two Year Increase } & \multicolumn{2}{|c|}{ Three Year Increase } \\
\hline & [1] & [2] & [3] & [4] & [5] & [6] \\
\hline \multirow[t]{2}{*}{ Ln(Assets) } & 0.005 & 0.014 & 0.009 & 0.013 & 0.03 & 0.026 \\
\hline & {$[0.781]$} & {$[0.426]$} & {$[0.556]$} & {$[0.405]$} & [0.129] & {$[0.160]$} \\
\hline \multirow[t]{2}{*}{ WB Gov. Index } & $1.025^{* * * *}$ & & 0.391 & & 0.165 & \\
\hline & [0.007] & & {$[0.283]$} & & {$[0.703]$} & \\
\hline \multirow[t]{2}{*}{ Ln(Assets)* WB Gov. Index } & $-0.087 * * *$ & & $-0.049 * * *$ & & $-0.050^{* * *}$ & \\
\hline & {$[0.000]$} & & {$[0.000]$} & & [0.004] & \\
\hline \multirow[t]{2}{*}{ ICRG Political Index } & & $1.874 * * *$ & & 0.443 & & -0.835 \\
\hline & & {$[0.001]$} & & [0.394] & & [0.109] \\
\hline \multirow[t]{2}{*}{ Ln(Assets)* ICRG Political Index } & & $-0.089 * * *$ & & $-0.053 * * *$ & & $-0.057 * * *$ \\
\hline & & [0.000] & & [0.000] & & [0.002] \\
\hline \multirow[t]{2}{*}{ Tobin's q } & 0.011 & 0.011 & $0.043^{* *}$ & $0.044^{* *}$ & 0.014 & 0.015 \\
\hline & {$[0.635]$} & {$[0.632]$} & {$[0.029]$} & {$[0.026]$} & {$[0.441]$} & {$[0.408]$} \\
\hline \multirow[t]{2}{*}{ Relative size } & 0.049 & 0.054 & 0.058 & 0.057 & $0.155 * * *$ & $0.151 * * *$ \\
\hline & {$[0.337]$} & {$[0.295]$} & {$[0.254]$} & {$[0.271]$} & [0.001] & [0.001] \\
\hline \multirow[t]{2}{*}{ Return on assets } & $2.747 * * *$ & $2.738 * * *$ & $0.375 * * *$ & $0.376^{* * *}$ & -0.219 & -0.211 \\
\hline & {$[0.000]$} & {$[0.000]$} & {$[0.008]$} & {$[0.008]$} & {$[0.134]$} & {$[0.147]$} \\
\hline \multirow[t]{2}{*}{ Leverage } & -0.355 & -0.35 & 0.039 & 0.047 & 0.117 & 0.14 \\
\hline & {$[0.152]$} & {$[0.155]$} & {$[0.878]$} & {$[0.852]$} & [0.539] & {$[0.463]$} \\
\hline \multirow[t]{2}{*}{ Cash-holdings } & $0.904 * * *$ & $0.911 * * *$ & $0.292 * *$ & $0.282^{* *}$ & $0.541 * * *$ & $0.530 * * *$ \\
\hline & [0.000] & [0.000] & {$[0.030]$} & {$[0.037]$} & [0.000] & [0.000] \\
\hline \multirow[t]{2}{*}{ CAPEX } & -0.123 & -0.133 & -0.436 & -0.447 & -0.064 & -0.067 \\
\hline & [0.647] & [0.619] & {$[0.137]$} & {$[0.125]$} & [0.864] & {$[0.858]$} \\
\hline \multirow[t]{2}{*}{ Diversifying } & $0.101^{* *}$ & $0.103^{* *}$ & -0.028 & -0.03 & -0.055 & -0.062 \\
\hline & {$[0.030]$} & {$[0.027]$} & {$[0.609]$} & {$[0.586]$} & {$[0.375]$} & {$[0.320]$} \\
\hline \multirow[t]{2}{*}{ Competed } & 0.328 & 0.321 & 0.07 & 0.057 & 0.231 & 0.211 \\
\hline & [0.133] & {$[0.143]$} & {$[0.741]$} & {$[0.788]$} & {$[0.260]$} & {$[0.305]$} \\
\hline \multirow[t]{2}{*}{ Tender } & 0.077 & 0.057 & -0.095 & -0.119 & -0.077 & -0.078 \\
\hline & {$[0.476]$} & [0.607] & {$[0.328]$} & {$[0.226]$} & {$[0.465]$} & {$[0.452]$} \\
\hline Friendly & -0.096 & -0.105 & -0.086 & -0.083 & -0.025 & -0.028 \\
\hline & [0.508] & [0.471] & [0.571] & [0.579] & [0.880] & [0.868] \\
\hline Cross-border & $-0.104 * *$ & $-0.110 * *$ & $-0.126 * *$ & $-0.126^{* *}$ & $-0.155^{* * *}$ & $-0.152 * * *$ \\
\hline & [0.030] & {$[0.022]$} & [0.016] & [0.016] & [0.009] & [0.010] \\
\hline Cash only & $-0.081 * *$ & $-0.079^{*}$ & 0.015 & 0.015 & $-0.095^{* *}$ & $-0.095^{* *}$ \\
\hline & [0.048] & [0.054] & {$[0.692]$} & {$[0.702]$} & [0.017] & [0.019] \\
\hline Stock only & $0.162 * * *$ & $0.166 * * *$ & -0.01 & -0.009 & $-0.136^{* *}$ & $-0.136^{* *}$ \\
\hline & [0.009] & [0.008] & [0.872] & [0.886] & [0.048] & [0.049] \\
\hline Public target & $-0.243^{* * *}$ & $-0.252 * * *$ & $-0.219 * * *$ & -0.213 *** & -0.106 & -0.094 \\
\hline & [0.000] & [0.000] & [0.002] & [0.002] & {$[0.154]$} & {$[0.200]$} \\
\hline Private target & $-0.087 *$ & $-0.091 *$ & $-0.088 * *$ & $-0.091 * *$ & -0.079 & -0.079 \\
\hline & {$[0.064]$} & {$[0.052]$} & [0.033] & [0.029] & {$[0.106]$} & {$[0.108]$} \\
\hline Home market capitalization & -9.143 & $-10.819^{*}$ & -7.031 & -7.318 & -5.559 & -4.151 \\
\hline & {$[0.152]$} & [0.085] & {$[0.232]$} & {$[0.205]$} & {$[0.336]$} & [0.473] \\
\hline Home turnover & 0.111 & 0.101 & 0.068 & 0.05 & 0.056 & 0.031 \\
\hline & {$[0.133]$} & [0.159] & [0.337] & {$[0.473]$} & {$[0.445]$} & [0.664] \\
\hline FDI & -0.234 & -0.105 & 0.562 & 0.534 & 0.044 & -0.139 \\
\hline & {$[0.762]$} & [0.894] & {$[0.422]$} & {$[0.454]$} & [0.946] & [0.835] \\
\hline Unemployment & 0.008 & 0.013 & -0.007 & -0.008 & $-0.029 * *$ & $-0.038 * *$ \\
\hline & {$[0.530]$} & {$[0.313]$} & {$[0.554]$} & {$[0.536]$} & {$[0.046]$} & [0.011] \\
\hline Trade imbalance & $-1.063 * * *$ & $-0.852 * *$ & $-1.148 * * *$ & $-1.106^{* * * *}$ & $-1.493 * * *$ & $-1.658 * * *$ \\
\hline & [0.008] & [0.037] & [0.002] & [0.002] & [0.000] & [0.000] \\
\hline Constant & -0.354 & $-1.234 *$ & -0.142 & -0.202 & -0.424 & 0.609 \\
\hline & {$[0.505]$} & {$[0.072]$} & {$[0.777]$} & {$[0.753]$} & [0.491] & {$[0.350]$} \\
\hline Observations & 15,049 & 15,001 & 15,048 & 15,000 & 15,047 & 14,999 \\
\hline Pseudo R-squared & $4.96 \%$ & $4.95 \%$ & $3.45 \%$ & $3.43 \%$ & $3.48 \%$ & $3.51 \%$ \\
\hline
\end{tabular}

